\title{
Aromatic C-F Hydroxylation by Nonheme Iron(IV)-Oxo Complexes: Structural, Spectroscopic, and Mechanistic Investigations
}

\author{
Sumit Sahu ${ }^{\dagger}$, Bo Zhang ${ }^{\ddagger} \S$, Christopher J. Pollock ${ }^{\ddagger} \S$, Maximilian Dürrll, Casey G. Davies ${ }^{\perp}$, \\ Alex M. Confer ${ }^{\dagger}$, Ivana Ivanović-Burmazovićll, Maxime A. Siegler ${ }^{\dagger}$, Guy N. L. Jameson ${ }^{*}, \perp$, \\ Carsten Krebs $\ddagger, \S,{ }^{*}$, and David P. Goldberg ${ }^{\dagger,}$
}

tDepartment of Chemistry, The Johns Hopkins University, 3400 North Charles Street, Baltimore, Maryland 21218, United States ‡Department of Chemistry, The Pennsylvania State University, University Park, Pennsylvania 16802, United States §Department of Biochemistry and Molecular Biology, The Pennsylvania State University, University Park, Pennsylvania 16802, United States II Department of Chemistry and Pharmacy, University of Erlangen-Nürnberg, 91058 Erlangen, Germany ${ }^{\perp}$ Department of Chemistry \& MacDiarmid Institute for Advanced Materials and Nanotechnology, University of Otago, PO Box 56, Dunedin 9054, New Zealand

\section{Abstract}

\begin{abstract}
The synthesis and reactivity of a series of mononuclear nonheme iron complexes that carry out intramolecular aromatic $\mathrm{C}-\mathrm{F}$ hydroxylation reactions is reported. The key intermediate prior to $\mathrm{C}-$ F hydroxylation, $\left[\mathrm{Fe}^{\mathrm{IV}}(\mathrm{O})-\left(\mathrm{N} 4 \mathrm{Py}^{2 \mathrm{Ar} 1}\right)\right]\left(\mathrm{BF}_{4}\right)_{2}\left(\mathbf{1 - O}, \mathrm{Ar}_{1}=-2\right.$,6-difluorophenyl), was characterized by single-crystal $\mathrm{X}$-ray diffraction. The crystal structure revealed a nonbonding $\mathrm{C}-$ $\mathrm{H} \cdots \mathrm{O}=\mathrm{Fe}$ interaction with a $\mathrm{CH}_{3} \mathrm{CN}$ molecule. Variable-field Mössbauer spectroscopy of 1-O indicates an intermediate-spin $(S=1)$ ground state. The Mössbauer parameters for 1-O include an unusually small quadrupole splitting for a triplet $\mathrm{Fe}^{\mathrm{IV}}(\mathrm{O})$ and are reproduced well by density functional theory calculations. With the aim of investigating the initial step for C-F hydroxylation, two new ligands were synthesized, N4Py ${ }^{2 \mathrm{Ar}_{2}}$ (L2, $\mathrm{Ar}_{2}=-2$,6-difluoro-4-methoxyphenyl) and $\mathrm{N}_{4} \mathrm{Py}^{2 \mathrm{Ar}_{3}}$ (L3, $\mathrm{Ar}_{3}=-2$,6-difluoro-3-methoxyphenyl), with -OMe substituents in the meta or orthol para positions with respect to the $\mathrm{C}-\mathrm{F}$ bonds. $\mathrm{Fe}^{\mathrm{II}}$ complexes $\left[\mathrm{Fe}\left(\mathrm{N} 4 \mathrm{Py}^{2 \mathrm{Ar}}\right)\left(\mathrm{CH}_{3} \mathrm{CN}\right)\right]-$ $\left(\mathrm{ClO}_{4}\right)_{2}(2)$ and $\left[\mathrm{Fe}\left(\mathrm{N} 4 \mathrm{Py}^{2} \mathrm{Ar}_{3}\right)\left(\mathrm{CH}_{3} \mathrm{CN}\right)\right]\left(\mathrm{ClO}_{4}\right)_{2}(3)$ reacted with isopropyl 2-iodoxybenzoate to give the $\mathrm{C}-\mathrm{F}$ hydroxylated $\mathrm{Fe}{ }^{\mathrm{III}}-\mathrm{OAr}$ products. The $\mathrm{Fe}^{\mathrm{IV}}(\mathrm{O})$ intermediates 2-O and 3-O were trapped at low temperature and characterized. Complex 2-O displayed a $\mathrm{C}-\mathrm{F}$ hydroxylation rate
\end{abstract}

\footnotetext{
“Corresponding Authors: gjameson@chemistry.otago.ac.nz.ckrebs@psu.edu.dpg@jhu.edu.

Notes

The authors declare no competing financial interest.

Supporting Information

The Supporting Information is available free of charge on the ACS Publications website at DOI: 10.1021/jacs.6b03346. Crystallographic information file for 1-O (CIF)

Crystallographic information file for $\mathbf{2}$ (CIF)

Crystallographic information file for 2-OAr (CIF)

Crystallographic information file for $\mathbf{4}$ (CIF)

Spectroscopic ( ${ }^{1} \mathrm{HNMR}, \mathrm{EPR}$, Mössbauer), mass spectrometric, kinetic and crystallographic data (PDF)
} 
similar to that of 1-O. In contrast, the kinetics (via stopped-flow UV-vis) for complex 3-O displayed a significant rate enhancement for $\mathrm{C}-\mathrm{F}$ hydroxylation. Eyring analysis revealed the activation barriers for the $\mathrm{C}-\mathrm{F}$ hydroxylation reaction for the three complexes, consistent with the observed difference in reactivity. A terminal $\mathrm{Fe}^{\mathrm{II}}(\mathrm{OH})$ complex (4) was prepared independently to investigate the possibility of a nucleophilic aromatic substitution pathway, but the stability of $\mathbf{4}$ rules out this mechanism. Taken together the data fully support an electrophilic C-F hydroxylation mechanism.

\section{Graphical Abstract}

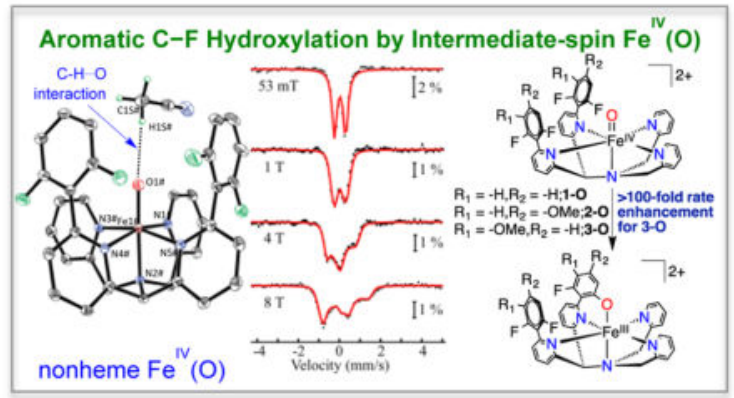

\section{INTRODUCTION}

The aromatic amino acid hydroxylases phenylalanine hydroxylase (PheH), tryptophan hydroxylase $(\mathrm{TrpH})$, and tyrosine hydroxylase $(\mathrm{TyrH})$ comprise a class of nonheme iron oxygenases that are responsible for the hydroxylation of aromatic rings on the amino acid side chain. The proposed mechanism of the catalytic cycle involves formation of a highvalent $\mathrm{Fe}^{\mathrm{IV}}(\mathrm{O})$ (ferryl) intermediate that carries out an electrophilic attack on the aromatic ring as the initial step in the hydroxylation reaction. ${ }^{1-3}$ Spectroscopic evidence for the intermediacy of an $\mathrm{Fe}^{\mathrm{IV}}(\mathrm{O})$ species is well-documented for TyrH and PheH. ${ }^{4,5}$ The analogous hydroxylation of aromatic substrates by synthetic nonheme iron complexes is known, but the nature of the active intermediate(s) has not been established. Both $\mathrm{Fe}^{\mathrm{IV}}(\mathrm{O})$ and $\mathrm{Fe}^{\mathrm{V}}(\mathrm{O})$ species were proposed as active oxidants in the absence of direct spectroscopic evidence. ${ }^{6-20}$

The spin state of $\mathrm{Fe}^{\mathrm{IV}}(\mathrm{O})$ species has been promoted as one of the key factors that determines reactivity. ${ }^{21-28}$ Nonheme iron enzymes, including the former hydroxylases, access high-spin $\left(S=2\right.$, quintet) $\mathrm{Fe}^{\mathrm{IV}}(\mathrm{O})$ intermediates, ${ }^{29,30}$ whereas most synthetic $\mathrm{Fe}^{\mathrm{IV}}(\mathrm{O})$ complexes exhibit intermediate-spin ( $S=1$, triplet) ground states. No intermediate-spin $\mathrm{Fe}^{\mathrm{IV}}(\mathrm{O})$ complexes were shown to promote aromatic hydroxylation, with the exception of a reaction with anthracene (but not with benzene or naphthalene) to give anthraquinone product. ${ }^{7}$ Only recently was aromatic hydroxylation by a synthetic high-spin $\mathrm{Fe}^{\mathrm{IV}}(\mathrm{O})$ complex reported. ${ }^{31}$ The generally enhanced reactivity of nonheme Fe enzymes as compared to that of the synthetic systems has been ascribed, in part, to the difference in spin ground state for the ferryl intermediate, and the observations regarding aromatic hydroxylation appear to follow this trend. The origin of the enhanced reactivity of a quintet versus triplet $\mathrm{Fe}^{\mathrm{IV}}(\mathrm{O})$ species has been debated and was examined mainly by computational studies. 
Calculations suggested that part of the reason for the low reactivity of triplet $\mathrm{Fe}^{\mathrm{IV}}(\mathrm{O})$ was because of steric clash between the incoming aromatic substrate and the equatorial ligands, which blocked access to the key $\pi^{*}$ acceptor orbitals on the $\mathrm{Fe}^{\mathrm{IV}}(\mathrm{O})$ unit. $6,7,25,32$

Recently, we provided experimental evidence showing that $\mathrm{Fe}^{\mathrm{IV}}(\mathrm{O})$ complexes are capable of aromatic hydroxylation provided that the aromatic substrate can be oriented properly in the second coordination sphere. ${ }^{15,33}$ In one case, we directly characterized the $\mathrm{Fe}^{\mathrm{IV}}(\mathrm{O})$ intermediate $\left[\mathrm{Fe}^{\mathrm{IV}}(\mathrm{O})\left(\mathrm{N} 4 \mathrm{Py}^{2 \mathrm{Ar} 1}\right)\right]^{2+}\left(\mathrm{Ar}_{1}=-2,6\right.$-difluorophenyl), and observed the intramolecular arene hydroxylation reaction for this system by UV-vis, Mössbauer, and cold-spray ionization mass spectrometry (CSIMS). This study provided only the second example of a well-characterized $\mathrm{Fe}^{\mathrm{IV}}(\mathrm{O})$ complex that could mediate arene hydroxylation. It also represented the first example of an aromatic C-F hydroxylation mediated by a nonheme iron complex. The tethered aromatic ring was fluorinated at the site of oxidation. ${ }^{33}$ Density functional theory (DFT) calculations suggested that this $\mathrm{Fe}^{\mathrm{IV}}(\mathrm{O})$ complex not only had a triplet ground state but also indicated that a quintet excited state may be close in energy. The presumed 6-coordinate geometry of this complex was consistent with a triplet state, although there were recent reports of quintet $\mathrm{Fe}^{\mathrm{IV}}(\mathrm{O})$ accommodated by a weak 6-coordinate ligand field. ${ }^{34,35}$ The low-field Mössbauer parameters of the $\mathrm{Fe}^{\mathrm{IV}}(\mathrm{O})$ complex exhibited the anticipated low isomer shift $\left(\delta=0.03 \mathrm{~mm} / \mathrm{s}\right.$ ) for an $\mathrm{Fe}^{\mathrm{IV}}(\mathrm{O})$ species, but the magnitude of the quadrupole splitting $\left(\Delta E_{\mathrm{Q}}=0.54 \mathrm{~mm} / \mathrm{s}\right)$ was noticeably smaller than that of other intermediate-spin $\mathrm{Fe}^{\mathrm{IV}}(\mathrm{O}) .{ }^{36}$ Thus, the spin ground state assignment for $\left[\mathrm{Fe}^{\mathrm{IV}}(\mathrm{O})\right.$ $\left.\left(\mathrm{N} 4 \mathrm{Py}^{2 \mathrm{Ar}}\right)\right]^{2+}$ was ambiguous. The spin-state assignment for the active $\mathrm{Fe}^{\mathrm{IV}}(\mathrm{O})$ intermediate is critical to understand whether intermediate spin $(S=1)$ nonheme $\mathrm{Fe}^{\mathrm{IV}}(\mathrm{O})$ complexes are inherently capable of performing these oxidation reactions.

The mechanism of $\mathrm{C}-\mathrm{F}$ hydroxylation for $\left[\mathrm{Fe}^{\mathrm{IV}}(\mathrm{O})-\left(\mathrm{N} 4 \mathrm{Py}^{2 \mathrm{Ar}} 1\right)\right]^{2+}$ was suggested to involve electrophilic attack of $\mathrm{Fe}^{\mathrm{IV}}(\mathrm{O})$ on the nearby aryl group. However, the difluorosubstituted phenyl groups are electron-poor, making electrophilic attack challenging. Fluoro-substituted phenyl rings are known to undergo nucleophilic substitution, including with a metal-bound hydroxide. ${ }^{37,38}$ An alternative mechanism would involve nucleophilic aromatic substitution by a putative $\mathrm{Fe}^{\mathrm{III}}(\mathrm{OH})$ intermediate, which could form via $\mathrm{H}$ atom transfer to $\mathrm{Fe}^{\mathrm{IV}}(\mathrm{O})$ from solvent or perhaps from a comproportionation reaction between $\mathrm{Fe}^{\mathrm{IV}}(\mathrm{O})$ and the starting $\mathrm{Fe}^{\mathrm{II}}$ complex.

In the current work we determine the spin state of the $\mathrm{Fe}^{\mathrm{IV}}(\mathrm{O})$ intermediate and identify the nature of the initial step in the mechanism of the $\mathrm{C}-\mathrm{F}$ hydroxylation by a combination of ligand design, reactivity studies, and spectroscopic methods. The $\mathrm{Fe}^{\mathrm{II}}$ complexes of two new ligands N4Py $2 \mathrm{Ar}_{2}\left(\mathrm{Ar}_{2}=-2\right.$,6-difluoro-4-methoxyphenyl) and $\mathrm{N} 4 \mathrm{Py}^{2 \mathrm{Ar}_{3}}\left(\mathrm{Ar}_{3}=-2,6-\right.$ difluoro-3-methoxyphenyl) were synthesized. These ligands were designed to include electron-donating methoxy substituents on the phenyl rings in either the meta or ortholpara positions in relation to the fluorine groups. Both of the new $\mathrm{Fe}^{\mathrm{II}}$ complexes undergo intramolecular aromatic $\mathrm{C}-\mathrm{F}$ hydroxylation upon reaction with the appropriate oxidant. The relative reactivity of these complexes, together with the synthesis of a new terminal iron(II)hydroxide complex, provide critical insight into the mechanism of $\mathrm{C}-\mathrm{F}$ hydroxylation. The geometric and electronic structure of the key metastable $\mathrm{Fe}^{\mathrm{IV}}(\mathrm{O})$ species was determined by variable-field Mössbauer spectroscopy, as well as by single-crystal X-ray crystallography. 


\section{RESULTS AND DISCUSSION}

\section{Structural Characterization of the Ferryl Intermediate $\left[\mathrm{Fe}^{\mathrm{IV}}(\mathrm{O})\left(\mathrm{N}_{4} \mathrm{Py}^{2 \mathrm{Ar}_{1}}\right)\right]\left(\mathrm{BF}_{4}\right)_{2}(\mathbf{1 - 0})$}

In an earlier report, it was shown that the $\mathrm{Fe}^{\mathrm{II}}$ precursor $\left[\mathrm{Fe}^{\mathrm{II}}\left(\mathrm{N} 4 \mathrm{Py}{ }^{2 \mathrm{Ar}}\right)\left(\mathrm{CH}_{3} \mathrm{CN}\right)\right]\left(\mathrm{BF}_{4}\right)_{2}(\mathbf{1}$, $\mathrm{Ar}_{1}=2$,6-difluorophenyl) reacted with $\mathrm{O}$ atom transfer agents to give the ferryl complex 1$\mathbf{O}$, which could be trapped at $-20{ }^{\circ} \mathrm{C}$ and characterized by UV-vis, low-field Mössbauer spectroscopy, and CSIMS. ${ }^{33}$ Upon warming, this complex readily converted to the arene hydroxylated product 1-OAr as shown in Scheme 1, and time-dependent studies confirmed 1-O was the reactive intermediate in this rare $\mathrm{C}-\mathrm{F}$ hydroxylation reaction. Given the novel reactivity of this $\mathrm{Fe}^{\mathrm{IV}}(\mathrm{O})$ complex, we were motivated to obtain the complete structural and electronic characterization of this complex by X-ray crystallography and variable-field Mössbauer spectroscopy. Although a number of synthetic nonheme $\mathrm{Fe}^{\mathrm{IV}}(\mathrm{O})$ complexes have been reported, only a few have been crystallographically characterized to date. ${ }^{39-45}$

The $\left[\mathrm{Fe}^{\mathrm{IV}}(\mathrm{O})\left(\mathrm{N} 4 \mathrm{Py}^{2 \mathrm{Ar} 1}\right)\right]^{2+}$ complex (1-O) was generated from the reaction of $\left[\mathrm{Fe}^{\mathrm{II}}\left(\mathrm{N} 4 \mathrm{Py}^{2 \mathrm{Ar}}\right)\left(\mathrm{CH}_{3} \mathrm{CN}\right)\right]^{2+}(\mathbf{1})$ and isopropyl 2-iodoxybenzoate (IBX-ester) at $-20{ }^{\circ} \mathrm{C}$.

Yellow crystals of 1-O were obtained by layering of $\mathrm{Et}_{2} \mathrm{O}$ into the $\mathrm{CH}_{3} \mathrm{CN}$ reaction mixture at $-70{ }^{\circ} \mathrm{C}$. The crystal structure of $\mathbf{1 - O}$ is given in Figure 1 and shows a 6-coordinate iron complex with a terminal oxo ligand in the open site. The short Fe-O distance of 1.6600(16) $\AA$ is characteristic of an iron(IV)-oxo complex. ${ }^{39-45}$ The Fe-N distances (1.9730(18)2.0511(17) $\AA$ ) are also in the expected range for an $\mathrm{Fe}^{\mathrm{IV}}(\mathrm{O})$ species. As depicted in Figure 1, a single $\mathrm{CH}_{3} \mathrm{CN}$ molecule is found in close proximity to the $\mathrm{Fe}^{\mathrm{IV}}(\mathrm{O})$ unit. The $\mathrm{H} \cdots \mathrm{O}$ distance $\left(2.54(3) \AA\right.$ ) and $\mathrm{C}-\mathrm{H} \cdots \mathrm{O}$ angle $\left(170(3)^{\circ}\right)$ indicate a non-bonding interaction between the methyl $\mathrm{C}-\mathrm{H}$ of the solvent molecule and the terminal oxo ligand. Similar nonbonding $\mathrm{C}-\mathrm{H} \cdots \mathrm{O}$ interactions have been observed in other structurally characterized $\mathrm{Fe}^{\mathrm{IV}}(\mathrm{O})$ complexes, but the $\mathrm{C}-\mathrm{H}-\mathrm{O}$ angles in these structures are significantly bent (100.4$\left.131.6^{\circ}\right) .{ }^{39,42,43}$ The experimentally determined $\mathrm{C}-\mathrm{H}-\mathrm{O}$ angle in $\mathbf{1 - O}$ is $170(3)^{\circ}$ and is the closest to linearity among the synthetic $\mathrm{Fe}^{\mathrm{IV}}(\mathrm{O})$ complexes. It is intriguing to consider that this interaction resembles the early stage of an $\mathrm{H}$ atom transfer from the $\mathrm{C}-\mathrm{H}$ bond to the $\mathrm{Fe}^{\mathrm{IV}}(\mathrm{O})$ unit.

The spin state of $\mathrm{Fe}^{\mathrm{IV}}(\mathrm{O})$ complex 1-O cannot be assigned from a simple analysis of the bond lengths in the crystal structure. As seen by comparison of the high- and intermediatespin $\mathrm{Fe}^{\mathrm{IV}}(\mathrm{O})$ species in Table 1, there is no clear experimentally observed trend seen for bond lengths versus observed spin ground state. ${ }^{46}$ However, it should be noted that the $S=2$ complexes in Table 1 are 5-coordinate species, whereas the $S=1$ complexes are 6coordinate. The enhanced reactivity of 1-O toward arene hydroxylation suggested that this complex could be an unusual 6-coordinate high-spin $\mathrm{Fe}^{\mathrm{IV}}(\mathrm{O})$. The only other characterized $\mathrm{Fe}^{\mathrm{IV}}(\mathrm{O})$ complex that mediates arene hydroxylation is a high-spin $S=2$ species. ${ }^{31} \mathrm{In}$ addition, low-field Mössbauer data showed that 1-O exhibits an isomer shift consistent with either intermediate- or high-spin $\mathrm{Fe}^{\mathrm{IV}}(\mathrm{O})$ but a quadrupole splitting closer to the high-spin complexes (Table 1). It is known that the addition of bulky aryl substituents ortho to pyridyl $\mathrm{N}$ donors results in the conversion of low-spin iron(II) to high-spin iron(II) complexes. ${ }^{15} \mathrm{We}$ thus sought to analyze the spin state of 1-O by variable-field Mössbauer spectroscopy. 


\section{Mössbauer Spectroscopy}

The electronic structure of $\left[\mathrm{Fe}^{\mathrm{IV}}(\mathrm{O})\left(\mathrm{N} 4 \mathrm{Py}^{2 \mathrm{Ar}}\right)\right]\left(\mathrm{BF}_{4}\right)_{2}(\mathbf{1 - O})$ was examined by variablefield Mössbauer spectroscopy. An ${ }^{57} \mathrm{Fe}$-enriched sample of 1-O was prepared from combining ${ }^{57} \mathrm{Fe}^{\mathrm{II}}\left(\mathrm{BF}_{4}\right)_{2}$ and free ligand in $\mathrm{CH}_{3} \mathrm{CN}$, followed by addition of the oxidant at $-20{ }^{\circ} \mathrm{C}$, as previously described. ${ }^{33}$ Analysis of the spectra (Figure 2, left panel, black vertical bars) reveals that $\sim 60 \%$ of the total intensity of the spectrum is attributable to 1-O. The remaining $\sim 40 \%$ of the total intensity emanates from one or more ferric complexes and can be reasonably well approximated by the experimental spectra of a duplicate sample that was allowed to decay for $40 \mathrm{~min}$ at room temperature (green lines). Removal of the contribution of the ferric decay product results in the reference spectra of 1-O (Figure 2, right panel, black vertical bars). The $4.2 \mathrm{~K} / 53 \mathrm{mT}$ Mössbauer spectrum of 1-O displays a quadrupole doublet with parameters $\left(\delta=0.03 \mathrm{~mm} / \mathrm{s}\right.$ and $\left.\Delta E_{\mathrm{Q}}=0.54 \mathrm{~mm} / \mathrm{s}\right)$ identical to those previously reported. ${ }^{33}$ While the isomer shift is typical of ferryl complexes, the absolute magnitude of the quadrupole splitting parameters is smaller than those observed for other ferryl complexes $\left(\Delta E_{\mathrm{Q}} \approx 1.2 \mathrm{~mm} / \mathrm{s}\right) .{ }^{36}$ However, spectroscopic parameters calculated using density functional theory (DFT) methods on geometry-optimized structures of 1-O and the extensively characterized intermediate-spin ferryl complex with 1,4,8,11tetramethylcyclam ligand $\left[(\mathrm{TMC}) \mathrm{Fe}^{\mathrm{IV}}(\mathrm{O})\left(\mathrm{CH}_{3} \mathrm{CN}\right)\right]^{2+}$ are in good agreement with the experimentally observed values (Table S1). The variable-field Mössbauer spectra of 1-O are similar to those previously reported for intermediate-spin $\mathrm{Fe}^{\mathrm{IV}}(\mathrm{O})$ complexes and establish that 1-O has a $S=1$ ground state. Because the spin Hamiltonian parameters required for analysis of the fielddependent spectra are correlated, ${ }^{47}$ we fixed the values of the A-tensor to those calculated for 1-O and allowed the remaining parameters to vary. This approach yields zero-field splitting (ZFS) parameters $D \approx 23 \mathrm{~cm}^{-1}$ and a small rhombicity ( $E / D$ ), i.e., values that are typical of intermediate-spin ferryl complexes. The nearly axial ZFS tensor with a positive $D$ produces a well-isolated ground state, which has a moderate spin expectation value in the $x y$ plane, $\left\langle S_{x}\right\rangle \approx\left\langle S_{y}\right\rangle$ but only a vanishingly small $\left\langle S_{z}\right\rangle$.

\section{New Aryl-Substituted Fell Complexes: Mechanistic Implications}

The C-F hydroxylation reaction observed for 1-O was unprecedented and suggested that an intermediate-spin $\mathrm{Fe}^{\mathrm{IV}}(\mathrm{O})$ species could function as a powerful oxidant provided that the substrate was oriented properly in the second coordination sphere. However, fluorinated aromatic rings are strongly resistant to electrophilic attack but are susceptible to nucleophilic aromatic substitution. There is also precedent for nucleophilic substitution of aryl C-F bonds by a metal-bound hydroxide intermediate. ${ }^{37} \mathrm{~A}$ similar nucleophilic pathway conceivably could occur if an intermediate $\mathrm{Fe}(\mathrm{OH})$ species was generated during the $\mathrm{C}-\mathrm{F}$ hydroxylation reaction for $\mathbf{1}$. In our previous report, we postulated that the $\mathrm{C}-\mathrm{F}$ hydroxylation reaction was likely initiated by electrophilic attack of $\mathrm{Fe}^{\mathrm{IV}}(\mathrm{O})$ on the difluorophenyl ring, although direct experimental evidence was lacking for this mechanism. Subsequent to our initial study, another example of nonheme-iron-mediated intramolecular $\mathrm{C}-\mathrm{F}$ hydroxylation was reported. ${ }^{20}$ The possibility of either an electrophilic or nucleophilic mechanism was invoked for the observed reactivity. However, no direct evidence for either mechanism was provided.

To probe the nature of the initial step of the C-F hydroxylation mechanism, the N4Py ${ }^{2 \mathrm{Ar}}$ ligand was modified with electron-donating methoxy substituents on the difluorophenyl 
rings. The new ligands $\mathrm{N} 4 \mathrm{Py}^{2} \mathrm{Ar}_{2}(\mathbf{L} 2)$ and $\mathrm{N} 4 \mathrm{Py}^{2} \mathrm{Ar}_{3}(\mathbf{L} 3)$ were prepared following a route similar to that for N4Py ${ }^{2 \mathrm{Ar}} 1$ (Scheme 2). ${ }^{33}$ The key step involved 2,6-difluoro-4-

methoxyphenylboronic acid (for L2) or 2,6-difluoro-3-methoxyphenylboronic acid (for L3) starting materials in Suzuki-Miyaura coupling reactions. Employing XPhos-Pd-G2 as the precatalyst, the resulting $\mathrm{C}-\mathrm{C}$ coupling products were obtained in reasonable yields (4965\%). The completed ligands $\mathbf{L} \mathbf{2}$ and $\mathbf{L} \mathbf{3}$ were synthesized according to Scheme 2 and isolated as pure solids after chromatography on basic alumina.

\section{Synthesis and Structure of a meta-OMe Substituted Fe"l Complex}

The reaction of $\mathrm{N} \mathrm{Py}^{2 \mathrm{Ar}}(\mathbf{L} 2)$, with an -OMe group positioned meta to the fluorine substituents, and $\mathrm{Fe}\left(\mathrm{ClO}_{4}\right)_{2}$ in $\mathrm{CH}_{3} \mathrm{CN}$ followed by vapor diffusion of $\mathrm{Et}_{2} \mathrm{O}$ yielded crystals of $\left[\mathrm{Fe}^{\mathrm{II}}\left(\mathrm{N} 4 \mathrm{Py}^{2 \mathrm{Ar}_{2}}\right)\left(\mathrm{CH}_{3} \mathrm{CN}\right)\right]\left(\mathrm{ClO}_{4}\right)_{2}$ (2). X-ray diffraction analysis (at 110(2) $\left.\mathrm{K}\right)$ of 2 revealed a six-coordinate iron complex with a $\mathrm{CH}_{3} \mathrm{CN}$ molecule in the open site (Figure 3). The Fe- $\mathrm{N}_{\mathrm{Py}}$ bond lengths (1.949(2)-2.063(2) $\AA$ ) seen in the crystal structure at 110(2) $\mathrm{K}$ are indicative of a low-spin (ls)-Fe ${ }^{2+}$ complex. ${ }^{48}$ The $\mathrm{Fe}-\mathrm{N}_{\mathrm{Py}}$ bonds carrying the fluorinated aryl rings are longer (2.063(2) and 2.030(2) $\AA$ ) than the other $\mathrm{Fe}-\mathrm{N}_{\mathrm{Py}}$ bonds (1.961(2) and $1.949(2) \AA$ ) because of steric interactions caused by the aryl substituents. ${ }^{15,33}$ Although the crystal structure indicates an 1s-Fe ${ }^{\mathrm{II}}$ species, the ${ }^{1} \mathrm{H}$ NMR spectrum for 2 in $\mathrm{CD}_{3} \mathrm{CN}$ at $297 \mathrm{~K}$ showed paramagnetically shifted peaks ( 100.3 to $-1.43 \mathrm{ppm})$. A solution-state Evans method measurement for 2 in $\mathrm{CD}_{3} \mathrm{CN}$ (at $297 \mathrm{~K}$ ) gave a magnetic moment value of $\mu_{\mathrm{eff}}=$ $4.0 \mu_{\mathrm{B}}$, consistent with high-spin (hs)- $\mathrm{Fe}^{2+}\left(S=2, \mu_{\mathrm{eff}}(\right.$ calcd $\left.)=4.9 \mu_{\mathrm{B}}\right)$. Mössbauer spectra $(4.2 \mathrm{~K})$ of $2\left(\left[{ }^{57} \mathrm{Fe}\left(\mathrm{N} 4 \mathrm{Py}^{2 \mathrm{Ar}_{2}}\right)\left(\mathrm{CH}_{3} \mathrm{CN}\right)\right]\left(\mathrm{ClO}_{4}\right)_{2}\right)$ in frozen solution revealed a mixture of 1sand hs-Fe ${ }^{2+}$ complexes (Figure S20). These data are consistent with population of both hsand $1 \mathrm{~s}-\mathrm{Fe}^{\mathrm{II}}$ for $\mathbf{2}$ in the solution state, which is also temperature-dependent.

\section{C-F Hydroxylation with 2}

The reaction of 2 at $23{ }^{\circ} \mathrm{C}$ with the $\mathrm{O}$ atom transfer reagent IBX-ester in $\mathrm{CH}_{3} \mathrm{CN}$ (Scheme 3) resulted in immediate decay (within $3 \mathrm{~min}$ ) of the $\mathrm{Fe}^{\mathrm{II}}$ peaks (460 and $370 \mathrm{~nm}$ ) and formation of a broad, weak band at $750 \mathrm{~nm}$. This band slowly converted into a relatively intense peak at $780 \mathrm{~nm}$ (Figure 4) over the next $\sim 40 \mathrm{~min}$. The weak band at $750 \mathrm{~nm}$ is characteristic of nonheme $\mathrm{Fe}^{\mathrm{IV}}(\mathrm{O})$ complexes and is similar to the UV-vis feature seen for 1-O. The final spectrum with a peak at $780 \mathrm{~nm}$ is close to that previously reported for $\mathrm{Fe}^{\mathrm{III}}$ $\mathrm{OAr}$ complex $\left[\mathrm{Fe}^{\mathrm{III}}\left(\mathrm{N} 4 \mathrm{Py}^{\mathrm{Ar}} 1, \mathrm{Ar}_{1} \mathrm{O}\right)\right]^{2+.33}$ Analysis of the final green solution by electrospray ionization mass spectrometry (ESIMS) revealed a parent ion at $\mathrm{m} / z$ 352.0784, indicating formation of the $\mathrm{C}-\mathrm{F}$ hydroxylated complex $\left[\mathrm{Fe}^{\mathrm{III}}\left(\mathrm{N} 4 \mathrm{Py}^{\mathrm{Ar}_{2}, \mathrm{Ar}_{2} \mathrm{O}}\right)\right]^{2+}(\mathrm{calcd} \mathrm{m} / z 352.0781)$. A peak for a chloride-associated ion, $\left[\mathrm{Fe}^{\mathrm{III}}\left(\mathrm{N} 4 \mathrm{Py} \mathrm{Ar}_{2}, \mathrm{Ar}_{2} \mathrm{O}\right) \mathrm{Cl}\right]^{+}(\mathrm{m} / z$ 739.1276), was also observed, where the ESIMS instrument likely provides the adventitious chloride.

Conclusive evidence of the occurrence of $\mathrm{C}-\mathrm{F}$ hydroxylation and the formation of the phenolate-bound iron complex was obtained by X-ray crystallography (Figure 5). Green crystals of the Fe $\mathrm{Fe}^{\mathrm{III}}-\mathrm{OAr}$ complex 2-OAr were obtained by vapor diffusion of $\mathrm{Et}_{2} \mathrm{O}$ into $\mathrm{CH}_{3} \mathrm{CN}$. The structure revealed a 6-coordinate $\mathrm{Fe}{ }^{\mathrm{III}}$ complex with the expected phenolate coordination resulting from hydroxylation of one of the $\mathrm{C}-\mathrm{F}$ bonds. The $\mathrm{Fe}-\mathrm{N}$ (1.921(2)$2.018(2) \AA$ ) and $\mathrm{Fe}-\mathrm{O}\left(1.814(2) \AA\right.$ ) bond lengths are consistent with 1s-Fe ${ }^{\mathrm{III}}$, which was further supported by the observation of a rhombic $S=1 / 2$ signal $[\mathrm{g}=(2.42,2.12,1.90)]$ in 
the X-band EPR spectrum (Figure S18). The signals with effective $g$-values of 6.37 and 4.24 in the EPR spectrum indicated the presence of a hs- $\mathrm{Fe}^{3+}$ species, which may arise from the $\left[\mathrm{Fe}^{\mathrm{III}}(\mathrm{F})\left(\mathrm{N} 4 \mathrm{Py}^{2 \mathrm{Ar}} 2\right)\right]^{2+}$ side-product generated during the reaction. The formation of an $\mathrm{Fe}^{\mathrm{III}}(\mathrm{F})$ species was observed in the previous example of $\mathrm{Fe}^{\mathrm{IV}}(\mathrm{O})$-mediated aromatic $\mathrm{C}-\mathrm{F}$ hydroxylation..$^{33}$ Manual isolation of the crystals of 2-OAr followed by molar absorptivity measurement of 2-OAr revealed $70 \%$ yield for the $\mathrm{C}-\mathrm{F}$ hydroxylated product at $23{ }^{\circ} \mathrm{C}$.

\section{Trapping the $\mathrm{Fe}^{\mathrm{IV}}(0)$ Intermediate (2-0)}

Performing the reaction of $\mathbf{2}+\mathrm{IBX}$-ester at $-20{ }^{\circ} \mathrm{C}$ (Scheme 3) and following by UV-vis revealed a weak absorption band at $\lambda_{\max }=750 \mathrm{~nm}$ consistent with formation of $\left[\mathrm{Fe}^{\mathrm{IV}}(\mathrm{O})\right.$ $\left.\left(\mathrm{N} \mathrm{Py}^{2 \mathrm{Ar}_{2}}\right)\right]^{+}$(2-O, Figure 6), similar to that observed for 1-O. ${ }^{33}$ This band is stable for at least $4 \mathrm{~h}$ at $-20{ }^{\circ} \mathrm{C}$. CSIMS of the solution at $-20{ }^{\circ} \mathrm{C}$ revealed the parent ion peak at 361.5774 , supporting the formation of $\left[\mathrm{Fe}^{\mathrm{IV}}(\mathrm{O})\left(\mathrm{N} \mathrm{Py}^{2 \mathrm{Ar}} 2\right)\right]^{2+}$ (calcd $\mathrm{m} / z 361.5773$ ), and the isotope distribution pattern indicated the presence of another complex with formula consistent with $\mathrm{Fe}^{\mathrm{III}}(\mathrm{OH})$ in approximately a 2:1 $\mathrm{Fe}^{\mathrm{IV}}(\mathrm{O}) / \mathrm{Fe}^{\mathrm{III}}(\mathrm{OH})$ ratio (Figure S9). Evidence for the formation of the ferryl species was obtained from Mössbauer spectroscopy (Figure S20). The $4.2 \mathrm{~K} / 53 \mathrm{mT}$ Mössbauer spectrum revealed that 2-O exhibits a quadrupole doublet with parameters ( $\delta=0.03 \mathrm{~mm} / \mathrm{s}, \Delta E_{\mathrm{Q}}=0.48 \mathrm{~mm} / \mathrm{s}$ ) almost identical to 1-O. The 4.2 $\mathrm{K} / 8 \mathrm{~T}$ spectrum further revealed that 2-O has a $S=1$ ground state (Figure S20).

\section{Kinetic Analysis for 2}

The observance of the $\mathrm{Fe}^{\mathrm{IV}}(\mathrm{O})$ intermediate $2-\mathrm{O}$ by $\mathrm{UV}$-vis allowed us to measure the rate of $\mathrm{C}-\mathrm{F}$ hydroxylation at room temperature $\left(23^{\circ} \mathrm{C}\right)$. The absorbance at $780 \mathrm{~nm}$ was plotted against time, assigning $t=0$ following the time required to form $\mathrm{Fe}^{\mathrm{IV}}(\mathrm{O})(750 \mathrm{~nm})$. Fitting of these data gave a first-order rate constant of $k_{2}=6.7( \pm 0.1) \times 10^{-2} \mathrm{~min}^{-1}$. The rate constant is independent of the concentration of the iron complex (Figure S13), consistent with the intramolecular nature of the reaction. Performing the reaction in the presence of excess IBX-ester (5 equiv) also did not have an effect on the rate of C-F hydroxylation (rate constant $\left.7.5( \pm 0.1) \times 10^{-2} \mathrm{~min}^{-1}\right)$. For the $\mathrm{C}-\mathrm{F}$ hydroxylation reaction mediated by the $\mathrm{Fe}^{\mathrm{IV}}(\mathrm{O})$ complex 1-O, a first-order rate constant of $k_{1}=5.13( \pm 0.06) \times 10^{-2} \mathrm{~min}^{-1}$ was reported. ${ }^{33}$ (the rate constant with 5 equiv of IBX-ester was found to be $8.2 \times 10^{-2}( \pm 0.1)$ $\min ^{-1}$ ). Thus, the presence of the methoxy groups in the meta position with respect to the fluorine substituents in $\mathbf{2}$ has little effect on the rate of the C-F hydroxylation reaction.

\section{Synthesis of an ortho-/para-OMe-Substituted Fe"l Complex}

Observing little effect of the meta-methoxy substituent on the rate of $\mathrm{C}-\mathrm{F}$ hydroxylation, we turned our attention toward preparing an $\mathrm{Fe}^{\mathrm{II}}$ complex of $\mathrm{N} 4 \mathrm{Py}^{2 \mathrm{Ar}} 3(\mathbf{L 3})$, with a methoxy substituent ortholpara to the $\mathrm{C}-\mathrm{F}$ bonds. $\left[\mathrm{Fe}\left(\mathrm{N} 4 \mathrm{Py}{ }^{2 \mathrm{Ar}} 3\right)\left(\mathrm{CH}_{3} \mathrm{CN}\right)\right]\left(\mathrm{ClO}_{4}\right)_{2}(3)$ was prepared similarly to complex $\mathbf{2}$, from the reaction of $\mathbf{L} \mathbf{2}$ with $\mathrm{Fe}\left(\mathrm{ClO}_{4}\right)_{2}$ in $\mathrm{CH}_{3} \mathrm{CN}$. Complex $\mathbf{3}$ was characterized by UV-vis $\left(\lambda_{\max }=373,460 \mathrm{~nm}\right),{ }^{1} \mathrm{H}$ NMR spectroscopy (paramagnetic spectrum in $\mathrm{CD}_{3} \mathrm{CN}$ at $24{ }^{\circ} \mathrm{C}$ ), and ESIMS (parent ion at $\mathrm{m} / \mathrm{z} 353.5798$, calcd $\mathrm{m} / z 353.5798$ for $\left.\left[\mathrm{Fe}^{\mathrm{II}}\left(\mathrm{N} 4 \mathrm{Py}^{2 \mathrm{Ar}}\right)\right]^{2+}\right)$. The Mössbauer spectrum $(4.2 \mathrm{~K})$ for a frozen solution of ${ }^{57} \mathrm{Fe}-$ labeled 3 showed the presence of both hs- and ls- $\mathrm{Fe}^{2+}$ complexes (Figure S21). 


\section{C-F Hydroxylation with 3}

The reaction of $\mathbf{3}$ with IBX-ester at $23{ }^{\circ} \mathrm{C}$ (Scheme 4) resulted in an immediate change ( 2 $\mathrm{min})$ in color from yellow to green with the appearance of a significantly red-shifted, stable peak at $915 \mathrm{~nm}\left(\varepsilon=1010 \mathrm{M}^{-1} \mathrm{~cm}^{-1}\right.$; based on total $\mathrm{Fe}$ ) (Figure 7). ESIMS analysis of the final green solution revealed a parent ion at $\mathrm{m} / z$ 739.1238, corresponding to the $\mathrm{C}-\mathrm{F}$ hydroxylated product with one $\mathrm{Cl}^{-}$associated $\left[\left(\mathrm{Fe}^{\mathrm{III}}\left(\mathrm{N} 4 \mathrm{Py}^{\mathrm{Ar}} 3, \mathrm{Ar}_{3} \mathrm{O}\right)\right)(\mathrm{Cl})\right]^{+}(\mathrm{calcd} \mathrm{m} / z$ 739.1260). X-band EPR spectra (Figure S19) confirmed the presence of $1 \mathrm{~s}-\mathrm{Fe}^{\mathrm{III}}[\mathbf{g}=(2.37$, 2.12, and 1.91)] similar to that of 2-OAr and other previously reported phenolate-bound $\mathrm{Fe}^{\mathrm{III}}$ complexes. ${ }^{15,33} \mathrm{~A}$ hs- $\mathrm{Fe}^{3+}$ signal was also observed in the EPR spectrum, which is likely due to the formation of the $\left(\left[\mathrm{Fe}^{\mathrm{III}}\left(\mathrm{N} 4 \mathrm{Py}^{2 \mathrm{Ar}}\right)(\mathrm{F})\right]^{2+}\right.$ complex. A peak in the ESIMS at $\mathrm{m} / z 761.1274$ supported this assignment (calcd $m / z$ for $\left[\mathrm{Fe}^{\mathrm{III}}\left(\mathrm{N} 4 \mathrm{Py}^{2 \mathrm{Ar}}\right)(\mathrm{F})(\mathrm{Cl})\right]^{+} 761.1279$, Figure S11). The observed UV-vis band at $915 \mathrm{~nm}$ for 3-OAr $\left(\left[\mathrm{Fe}^{\mathrm{III}}\left(\mathrm{N} 4 \mathrm{Py}^{\mathrm{Ar}} 3, \mathrm{Ar}_{3} \mathrm{O}\right)\right]^{2+}\right)$ is considerably red-shifted compared to that seen for either 1-OAr (no OMe substitution) or 2OAr (meta-substituted-OMe). ${ }^{33}$ A similar red-shift in a phenolate-to-Fe ${ }^{\mathrm{III}}$ charge-transfer band was observed for an Fe $\mathrm{F}^{\mathrm{III}}$-TPA derivative upon substitution of an electron-donating methyl group para to the phenolate donor. ${ }^{9}$ In contrast to the reaction of $\mathbf{2}+$ IBX-ester, no evidence for an intermediate $\mathrm{Fe}^{\mathrm{IV}}(\mathrm{O})$ species was observed by $\mathrm{UV}$-vis at $23^{\circ} \mathrm{C}$.

\section{Trapping the $\mathrm{Fe}^{\mathrm{IV}}(\mathrm{O})$ Intermediate (3-O)}

To trap the $\mathrm{Fe}^{\mathrm{IV}}(\mathrm{O})$ intermediate, the reaction of $\mathbf{3}+\mathrm{IBX}$-ester was performed at $-20{ }^{\circ} \mathrm{C}$. UV-vis analysis showed formation of the $755 \mathrm{~nm}$ band associated with $\mathrm{Fe}^{\mathrm{IV}}(\mathrm{O})(\mathbf{3 - O})$, but unlike meta-substituted 2-O, this species was not stable at $-20{ }^{\circ} \mathrm{C}$, converting to the $\mathrm{C}-\mathrm{F}$ hydroxylated product 3-OAr. Lowering the temperature further to $-35^{\circ} \mathrm{C}$ resulted in stabilization of the $755 \mathrm{~nm}$ band (Figure 8). ${ }^{1} \mathrm{H}$ NMR spectroscopy of the reaction mixture revealed a paramagnetic spectrum with distinct, relatively sharp peaks at $49,-10$, and -25 ppm. The ${ }^{1} \mathrm{H}$ NMR spectra for 1-O and 2-O at $-20{ }^{\circ} \mathrm{C}$ also revealed similar paramagnetically shifted peaks (Figure S6), supporting the assignment of the ferryl complex 3-O. The presence of the $\mathrm{Fe}^{\mathrm{IV}}(\mathrm{O})$ complex at $-35^{\circ} \mathrm{C}$ was further demonstrated by CSIMS, which revealed a parent ion peak at $m / z 362.0802$ (calcd $m / z$ for $\left[\mathrm{Fe}^{\mathrm{IV}}(\mathrm{O})\right.$ $\left.\left.\left(\mathrm{N} 4 \mathrm{Py}^{2 \mathrm{Ar} 3}\right)\right]^{2+} 361.5773\right)$. Analysis of the isotope distribution pattern indicated almost an equal proportion of $\left[\mathrm{Fe}^{\mathrm{IV}}(\mathrm{O})\left(\mathrm{N} 4 \mathrm{Py}^{2 \mathrm{Ar}} 3\right)\right]^{2+}(\mathbf{3 - O})$ and $\left[\mathrm{Fe}^{\mathrm{III}}(\mathrm{OH})\left(\mathrm{N}_{4} \mathrm{Py}^{2 \mathrm{Ar}}\right)\right]^{2+}$ species (Figure S12).

Attempted Mössbauer characterization of 3-O from the reaction of $\left[{ }^{57} \mathrm{Fe}^{\mathrm{II}}\left(\mathrm{N} 4 \mathrm{Py}{ }^{2 \mathrm{Ar}} 3\right)\right.$ $\left.\left(\mathrm{CH}_{3} \mathrm{CN}\right)\right]\left(\mathrm{ClO}_{4}\right)_{2}+\mathrm{IBX}$-ester at $-35^{\circ} \mathrm{C}$ revealed mostly an $\mathrm{Fe}{ }^{\mathrm{III}}$ signal and thus was not successful. The difficulties in trapping 3-O by Mössbauer spectroscopy are possibly due to a comproportionation reaction between the initially formed $\mathrm{Fe}^{\mathrm{IV}}(\mathrm{O})$ and unreacted $\mathrm{Fe}^{\mathrm{II}}$. The relatively high concentration of $\mathrm{Fe}^{\mathrm{II}}$ required for Mössbauer analysis and slow kinetics for the reaction between $3+\mathrm{IBX}$-ester at $-35^{\circ} \mathrm{C}$ both would facilitate the intermolecular reaction between the $\mathrm{Fe}^{\mathrm{II}}$ and $\mathrm{Fe}^{\mathrm{IV}}$ species. The lower yield for 3-O at low reaction temperature was also reflected in the lower yield for 3-OAr that arises when the $\mathrm{Fe}^{\mathrm{IV}}(\mathrm{O})$ species generated at $-35{ }^{\circ} \mathrm{C}$ was warmed to room temperature $\left(21^{\circ} \mathrm{C}\right)$, compared to the yield that was obtained when $\mathbf{3}+\mathrm{IBX}$-ester was performed at $21^{\circ} \mathrm{C}$ (Figure S23). To minimize the possibility of $\mathrm{Fe}^{\mathrm{IV}}(\mathrm{O})$ decay, a rapid-freeze-quench technique was applied for the reaction between ${ }^{57} \mathrm{Fe}$-labeled $\mathbf{3}+\mathrm{IBX}$-ester at $-5{ }^{\circ} \mathrm{C}$, and the reaction was probed by 
time-dependent Mössbauer spectroscopy (Figure S21). Analysis of the frozen reaction mixture at early time intervals reveals hs- and ls- $\mathrm{Fe}^{\mathrm{II}}$ signals from starting material and a new intermediate with parameters consistent with a low- or intermediate-spin $\mathrm{Fe}^{\mathrm{II}}$ species (formed within $18 \mathrm{~s}$ ). These species begin to decay before the appearance of the $\mathrm{Fe}^{\mathrm{IV}}(\mathrm{O})$ species (formed by $\sim 22 \mathrm{~s}$, and decay by $\sim 29 \mathrm{~s}$ ). The new, putative $\mathrm{Fe}^{\mathrm{II}}$ intermediate was not characterized, although a reasonable possibility for its identity is an $\mathrm{Fe}^{\mathrm{II}}$ (IBX-ester) precursor complex on the way to the $\mathrm{Fe}^{\mathrm{IV}}(\mathrm{O})$ species. The ferryl complex 3-O exhibited a quadrupole doublet with isomer shift of $0.03 \mathrm{~mm} / \mathrm{s}$ and quadrupole splitting of $0.50 \mathrm{~mm} / \mathrm{s}$ (Figure 8), similar to those observed for complexes 1-O and 2-O, and suggesting that it has a similar electronic structure.

\section{Kinetic Analysis for 3}

Stopped-flow UV-vis spectroscopy was used to detect the $\mathrm{Fe}^{\mathrm{IV}}(\mathrm{O})$ intermediate and obtain the rate constant for $\mathrm{C}-\mathrm{F}$ hydroxylation in the reaction of $\mathbf{3}$ with IBX-ester at room temperature $\left(22{ }^{\circ} \mathrm{C}\right)$. Mixing of $\mathbf{3}$ with IBX-ester in $\mathrm{CH}_{3} \mathrm{CN}$ led to the formation of the $\mathrm{Fe}^{\mathrm{IV}}(\mathrm{O})(3-\mathrm{O})$ species $\left(\lambda_{\max }=755 \mathrm{~nm}\right)$ within $0.75 \mathrm{~s}$, which then converted to the aryl hydroxylated complex 3-OAr $\left(\lambda_{\max }=915 \mathrm{~nm}\right)$ over $\sim 35 \mathrm{~s}$. Fitting of the data for the conversion of 3-O to 3-OAr led to a first-order rate constant of $k_{3}=8.0( \pm 0.04) \mathrm{min}^{-1}$ (Figure 7). This value is significantly higher than the rate constant obtained for 1-O $(\sim 160$ fold increase), as well as for the meta-methoxysubstituted 2-O ( 120 fold increase). The presence of the electron-donating-OMe group in the ortholpara position in relation to the $\mathrm{C}-\mathrm{F}$ bonds results in a large increase in reaction rate.

\section{Possible Mechanisms}

Two possible pathways for the initial attack of the iron-bound $\mathrm{O}$ atom on the difluorophenyl ring can be envisioned and are shown in Scheme 5. The mechanism in Scheme 5A involves electrophilic attack on the arene ring by $\mathrm{Fe}^{\mathrm{IV}}(\mathrm{O})$. Scheme 5B involves nucleophilic attack by a one-electron reduced iron(III)-hydroxide intermediate. It is important to consider this pathway as significant amounts of $\mathrm{Fe}^{\mathrm{III}}(\mathrm{OH})$ were seen during the formation of the ferryl complexes, particularly 2-O and 3-O. The thermal stabilities and relative rates of $\mathrm{C}-\mathrm{F}$ hydroxylation for 1-O, 2-O, and 3-O provide insight into the mechanism of this initial step. Our mechanistic analysis rests on the assumption that the reaction proceeds by the same mechanism involving the ferryl intermediates 1-O, 2-O, and 3-O, which have been trapped and shown to exhibit similar spectroscopic parameters. These data in turn suggest that their electronic structures are similar, as can be expected based on the similarity of the ligands.

Addition of an electron-donating -OMe group to the ortho/ para position relative to the $\mathrm{C}-\mathrm{F}$ bonds can be expected to increase the rate of the electrophilic pathway because of its ability to stabilize the electron-deficient radical intermediate through resonance delocalization. A decrease in the rate of the nucleophilic pathway is also expected due to the same reasoning. In contrast, substitution at the meta position should have little influence on the rate of either pathway because it is not in conjugation with either radical or anionic intermediates (Scheme 5). The lower thermal stability of $\mathrm{Fe}^{\mathrm{IV}}(\mathrm{O})$ and enhanced reactivity of $\mathrm{C}-\mathrm{F}$ hydroxylation for the $o-/ p$-OMesubstituted complex $\mathbf{3}$, as compared to the unsubstituted $\mathbf{1}$ and $m$-OMe-substituted $\mathbf{2}$, clearly point to the electrophilic mechanism, shown in pathway 
A. The lack of an effect for the $m$-OMe-substitution versus unsubstituted $\mathbf{1}$ is also consistent with this conclusion. We propose that the radical intermediate in Scheme 5A likely gets reduced by one electron, which can subsequently release fluoride to form the final C-F hydroxylated product. The source of the reducing equivalent has not been definitively characterized.

\section{Activation Parameters}

Temperature-dependent studies on the rate-constants $\left(k_{1}, k_{2}\right.$, and $\left.k_{3}\right)$ were performed on complexes 1-3 to obtain the activation parameters for the hydroxylation reactions. The plots of $\ln (k / T)$ versus $1 / T$ (Eyring plot) for the conversion of $\mathrm{Fe}^{\mathrm{IV}}(\mathrm{O})$ to $\mathrm{Fe}^{\mathrm{III}}(\mathrm{OAr}$ ) complex (20$45^{\circ} \mathrm{C}$ for $\mathbf{1}$ and $\mathbf{2}, 22$ to $-15{ }^{\circ} \mathrm{C}$ for $\mathbf{3}$ ) revealed a linear dependence as shown in Figure S17. Activation parameters $\left(\Delta H^{\ddagger}\right.$ and $\Delta S^{\dagger}$ ) were obtained and are given in Table 2. For the complexes $\mathbf{1}$ and $\mathbf{2}$, although the enthalpic $\left(\Delta H^{\dagger}\right)$ and entropic contributions $\left(\Delta S^{\dagger}\right)$ of the activation energies show some differences, the free energies of activation $\left(\Delta G^{\dagger}\right)$ at $298 \mathrm{~K}$ are nearly identical. This similarity is expected given the similar reaction rates. The observed entropic contributions to the activation barriers are smaller here compared to bimolecular reactions involving $\mathrm{Fe}^{\mathrm{IV}}(\mathrm{O})$ complexes ${ }^{7,49,50}$ and are indicative of an intramolecular mechanism. Moreover, $\Delta H^{\ddagger}$ and $\Delta G^{\dagger}$ for the conversion of 1-O to 1-OAr match very well with those values obtained from previous DFT calculations where an electrophilic pathway was proposed (Table 2). ${ }^{33}$ Analysis of the Eyring plot for 3-O to 3-OAr revealed that the enthalpic and Gibbs free energy of activation for the $o, p$-OMe-substituted complex is smaller than the other two complexes (1-O and 2-O) by at least $5 \mathrm{kcal} / \mathrm{mol}$. The smaller activation barrier for 3-O is consistent with the observed reactivity pattern, where 3-O undergoes the $\mathrm{C}-\mathrm{F}$ hydroxylation reaction at a faster rate compared to the rates observed for 1-O and 2-O. These data further support the assignment of an intramolecular electrophilic pathway for $\mathrm{C}-\mathrm{F}$ hydroxylation.

\section{Synthesis of a Terminal Fe"l $(\mathrm{OH})$ Complex}

A final experiment to eliminate the possibility of nucleophilic attack as the initial step in CF hydroxylation (Scheme 5B) involved the synthesis of an $\mathrm{Fe}^{\mathrm{II}}(\mathrm{OH})$ complex. The complex $\left[\mathrm{Fe}^{\mathrm{II}}(\mathrm{OH})-\left(\mathrm{N} 4 \mathrm{Py}^{2 \mathrm{Ar}} 1\right)\right]\left(\mathrm{ClO}_{4}\right)(4)$ was prepared from the reaction of the $\mathrm{Fe}^{\mathrm{II}}\left(\mathrm{CH}_{3} \mathrm{CN}\right)$ complex and $\mathrm{NaOH}$ in $\mathrm{CH}_{2} \mathrm{Cl}_{2}$ (Scheme 6). Dark red crystals of $\mathbf{4}$ were obtained from the layering of pentane with $\mathrm{CH}_{2} \mathrm{Cl}_{2}$. X-ray diffraction analysis of crystals of 4 revealed the presence of a terminal -OH group in the open site of the 6-coordinate $\mathrm{Fe}^{\mathrm{II}}$ complex (Figure $9)$. The $\mathrm{H}$ atom attached to the hydroxide was found from difference Fourier maps. The $\mathrm{Fe}-$ $\mathrm{N}$ bond lengths (2.167(4)-2.304(4) $\AA$ and 2.175(4)-2.300(4) $\AA$ for two crystallographically independent cations) are indicative of a hs- $\mathrm{Fe}^{\mathrm{II}}$ center in 4 . The $\mathrm{Fe}-\mathrm{O}$ bond distance (1.907(3) and 1.914(3) $\AA$ ) is consistent with that of other structurally characterized $\mathrm{Fe}^{\mathrm{II}}(\mathrm{OH})$ complexes. ${ }^{51-53}$

The $\mathrm{Fe}^{\mathrm{II}}(\mathrm{OH})$ complex $\mathbf{4}$ is stable both in the solid state as well as in solution upon redissolving the crystalline solid. No evidence for $\mathrm{C}-\mathrm{F}$ hydroxylation was observed even upon prolonged standing in $\mathrm{CH}_{2} \mathrm{Cl}_{2}$. Treatment of the free ligand $\mathrm{N} 4 \mathrm{Py}^{2 \mathrm{Ar}}$ ( (L1) with excess $\mathrm{NaOH}$ also does not lead to the substitution of the $\mathrm{C}-\mathrm{F}$ group. Attempts to prepare analogous $\mathrm{Fe}^{\mathrm{III}}(\mathrm{OH})$ were unsuccessful. However, given that a putative $\mathrm{Fe}^{\mathrm{III}}(\mathrm{OH})$ 
intermediate (Scheme 5B) should be less nucleophilic than either $\mathbf{4}$ or free $\mathrm{OH}^{-}$, it can be concluded that the nucleophilic pathway is not relevant here.

\section{Summary and Conclusions}

$\mathrm{Fe}^{\mathrm{IV}}(\mathrm{O})$ complex 1-O formed during the intramolecular $\mathrm{C}-\mathrm{F}$ hydroxylation reaction was isolated at low temperature and characterized by singlecrystal XRD. The crystal structure revealed the expected $\mathrm{Fe}^{\mathrm{IV}}(\mathrm{O})$ structure along with a nonbonding $\mathrm{C}-\mathrm{H} \cdots \mathrm{O}$ interaction between $\mathrm{Fe}^{\mathrm{IV}}(\mathrm{O})$ and $\mathrm{CH}_{3} \mathrm{CN}$. The spin ground state of this complex could not be determined by previous low-field Mössbauer measurements. Variable-field Mössbauer spectroscopy, together with DFT calculations, was successful in providing a definitive assignment of an intermediate-spin $(S=1)$ ground state for 1-O.

The hydroxylation of C-F bonds by a nonheme iron(IV)- oxo complex was unprecedented prior to our initial report, ${ }^{33}$ and we wanted to establish the role of the $\mathrm{Fe}^{\mathrm{IV}}(\mathrm{O})$ complex in this process. There are two general mechanisms that can be envisioned, the first being electrophilic attack of $\mathrm{Fe}^{\mathrm{IV}}(\mathrm{O})$ on the fluorinated aromatic ring and the second being nucleophilic aromatic substitution by an $\mathrm{Fe}^{\mathrm{IV}}(\mathrm{O})$-derived nucleophile. We reasoned that if the mechanism followed electrophilic attack, it would be enhanced by the addition of electrondonating substituents to the aromatic ring in the appropriate positions. With this hypothesis in hand, new Fe ${ }^{\mathrm{II}}$ complexes $\mathbf{2}$ and $\mathbf{3}$ were synthesized, which incorporated electron-donating -OMe substituents in meta (2) or ortholpara (3) positions, respectively. Both complexes underwent $\mathrm{C}-\mathrm{F}$ hydroxylation as seen for $\mathbf{1}$, and an $\mathrm{Fe}^{\mathrm{IV}}(\mathrm{O})$ intermediate in both cases could be trapped at low temperature. The meta-substituted $\mathrm{Fe}^{\mathrm{IV}}(\mathrm{O})$ complex 2-O exhibited similar reaction rates to that of 1-O, but the rate of $\mathrm{C}-\mathrm{F}$ hydroxylation for ortho-/ para-substituted 3-O was significantly higher (>100-fold) than that of either 1-O or 2-O. The reactivity pattern for 1-O, 2-O, and 3-O provides strong evidence that $\mathrm{C}-\mathrm{F}$ hydroxylation occurs by electrophilic attack of the $\mathrm{Fe}^{\mathrm{IV}}(\mathrm{O})$ on the arene ring. In addition, the synthesis and crystallographic characterization of iron(II)- hydroxide complex $\left[\mathrm{Fe}^{\mathrm{II}}(\mathrm{OH})\left(\mathrm{N} 4 \mathrm{Py}^{2 \mathrm{Ar}} 1\right)\right]^{+}$ allowed us to examine the propensity for nucleophilic aromatic substitution of the internal $\mathrm{C}-\mathrm{F}$ bonds. This pathway was ruled out because of the high stability of $\left[\mathrm{Fe}^{\mathrm{II}}(\mathrm{OH})\right.$ $\left.\left(\mathrm{N} 4 \mathrm{Py}^{2 \mathrm{Ar}} 1\right)\right]^{+}$and a lack of any evidence for substitution of the $\mathrm{C}-\mathrm{F}$ groups by hydroxide.

Aromatic hydroxylation is an important biochemical process and is mediated by the nonheme iron aromatic amino acid hydroxylases (TyrH, $\mathrm{PheH}$, and $\mathrm{TrpH})$. Spectroscopic and biochemical studies have pointed to a high-spin $(S=2) \mathrm{Fe}^{\mathrm{IV}}(\mathrm{O})$ as the reactive oxidant, which performs the key electrophilic attack on the aromatic substrate. Although nonheme iron model complexes were known to mediate aromatic hydroxylation, the active hydroxylating species could not be identified in these previous studies, except for a recent example of a hs- $\mathrm{Fe}^{\mathrm{IV}}(\mathrm{O})$ that undergoes intramolecular arene hydroxylation. ${ }^{31} \mathrm{In}$ this work we have demonstrated that intermediatespin $(S=1) \mathrm{Fe}^{\mathrm{IV}}(\mathrm{O})$ species are capable of mediating aromatic hydroxylation, even with inert, electron-deficient $\mathrm{C}-\mathrm{F}$ substituents. We have also expanded the set of well-characterized $\mathrm{Fe}^{\mathrm{IV}}(\mathrm{O})$ species that carry out aromatic hydroxylation with the synthesis of two new $\mathrm{Fe}^{\mathrm{IV}}(\mathrm{O})$ complexes.

These results support the conclusion that a triplet $\mathrm{Fe}^{\mathrm{IV}}(\mathrm{O})$ can carry out challenging oxidations on par with quintet $\mathrm{Fe}^{\mathrm{IV}}(\mathrm{O})$, provided that the substrate can be positioned 
properly in the second coordination sphere. We believe this study also highlights the power of synthetic inorganic chemistry to address fundamental mechanistic questions of biological relevance through ligand design and trapping of metastable intermediates. Similar studies regarding electrophilic and nucleophilic reactivity of $\mathrm{Fe}^{\mathrm{IV}}(\mathrm{O})$ intermediates would be very difficult to perform directly on an enzymatic system.

\section{EXPERIMENTAL SECTION}

\section{Materials and Methods}

All reagents and chemicals were purchased from commercial sources and were used without further purification. The solvents were purified via Pure-Solv Solvent Purification System from Innovative Technology, Inc. Solvents used for inorganic reactions involving iron(II) complexes were subjected to additional purification steps. Acetonitrile was distilled over calcium hydride. All solvents were degassed by freeze-pump-thaw cycles and stored in a $\mathrm{N}_{2}$-filled drybox until ready for use. All the reactions were performed under inert atmosphere (using either standard Schlenk techniques or in a $\mathrm{N}_{2}$-filled drybox) unless otherwise noted. Bis(6-bromopyridin-2-yl)-methanone, ${ }^{54}$ isopropyl 2-iodoxybenzoate (IBXester $){ }^{55}\left[\mathrm{Fe}^{\mathrm{II}}\left(\mathrm{N} 4 \mathrm{Py}{ }^{2 \mathrm{Ar}} 1\right)\left(\mathrm{CH}_{3} \mathrm{CN}\right)\right]\left(\mathrm{BF}_{4}\right)_{2} /\left(\mathrm{ClO}_{4}\right)_{2}$, and $\left[{ }^{57} \mathrm{Fe}^{\mathrm{IV}}(\mathrm{O})\left(\mathrm{N} 4 \mathrm{Py}^{2 \mathrm{Ar} 1}\right)\right]\left(\mathrm{BF}_{4}\right)_{2}{ }^{33}$ were also prepared according to previously reported procedures.

\section{Instrumentation}

UV-visible spectra were recorded on a Varian Cary 50 Bio spectrophotometer and on an Agilent 5453 diode-array spectrophotometer. Low-temperature UV-vis experiments were carried out in a custom-made Schlenk flask fitted with a fiber optical UV-vis immersion probe ( $2 \mathrm{~mm}$ path length). Stopped-flow experiments were performed in a HiTech SHU-61SX2 (TgK scientific Ltd.) with xenon light source. The data was processed using Kinetic Studio software. Variable-temperature kinetic experiments (Eyring analysis) were performed on a Cary bio-50 spectrophotometer equipped with a Unisoku USP-203A cryostat using a $1 \mathrm{~cm}$ cuvette. NMR data were collected on either a Bruker Avance $400 \mathrm{MHz}$ FTNMR spectrometer $\left({ }^{1} \mathrm{H}\right)$ or a Bruker $300 \mathrm{MHz}$ FT-NMR spectrometer $\left({ }^{19} \mathrm{~F}\right)$. Electron paramagnetic resonance (EPR) spectra were obtained on a Bruker EMX EPR spectrometer controlled with a Bruker ER 041 X G microwave bridge. The spectrometer was equipped with a continuous-flow liquid He cryostat and an ITC503 temperature controller made by Oxford Instruments, Inc. Mössbauer spectra were recorded on spectrometers from SEECO (Edina, MN). The spectrometer used to acquire the weakfield spectra of 1-O and 2-O is equipped with a Janis SVT-400 variabletemperature cryostat. The spectrometer used to acquire the strong-field spectra of 1-O and 2-O is equipped with a Janis 8TMOSSOM-12SVT variable-temperature cryostat. The spectrometer used to acquire the spectra of 3-O is equipped with a closed-cycle refrigerator system from Janis Research Co. and SHI (Sumitomo Heavy Industries, Ltd.). The external magnetic field was applied parallel to the $\gamma$ beam. All isomer shifts quoted are relative to the centroid of the spectrum of $a$-iron metal at room temperature. Simulation of the Mössbauer spectra was carried out by using the WMOSS spectral analysis software from SEECO (www.wmoss.org; Edina, MN). For simulation of spectra in applied external fields, the commonly used spin-Hamiltonian formalism was used (eq 1), in which the first three terms represent the electron Zeeman 
effect and zero field splitting (ZFS) of the electron-spin ground state, the fourth term represents the interaction between the electric field gradient and the nuclear quadrupole moment, the fifth term describes the magnetic hyperfine interactions of the electronic spin with the ${ }^{57} \mathrm{Fe}$ nucleus, and the last term represents the ${ }^{57} \mathrm{Fe}$ nuclear Zeeman interaction.

$$
\begin{gathered}
\mathbf{H}=\beta \mathbf{S} \bullet \mathbf{g} \bullet \mathbf{B}+D\left(\mathbf{S}_{z}^{2}-\frac{S(S+1)}{3}\right)+E\left(\mathbf{S}_{x}^{2}-\mathbf{S}_{y}^{2}\right) \\
+\frac{\mathbf{e Q V} z z}{4}\left[\mathbf{I}_{z}^{2}-\frac{I(I+1)}{3}+\frac{\eta}{3}\left(\mathbf{I}_{x}^{2}-\mathbf{I}_{y}^{2}\right)\right]+\mathbf{S} \bullet \mathbf{A} \bullet \mathbf{I} \\
-g_{n} \beta_{n} \mathbf{B} \bullet \mathbf{I}
\end{gathered}
$$

FAB-MS was obtained using a VG analytical VG-70SE magnetic sector mass spectrometer. Cryospray-ionization MS (CSI-MS) measurements were performed on a UHR-TOF Bruker Daltonik (Bremen, Germany) maXis plus, an ESI-quadrupole time-of-flight (qToF) mass spectrometer capable of resolution of at least $60000 \mathrm{fwhm}$, which was coupled to a Bruker Daltonik Cryospray unit. Detection was in positive ion mode; the source voltage was $3.8 \mathrm{kV}$. The flow rates were $280 \mu \mathrm{L} /$ hour. The drying gas $\left(\mathrm{N}_{2}\right)$, to aid solvent removal, was held at $-35{ }^{\circ} \mathrm{C}$, and the spray gas was held at $-40{ }^{\circ} \mathrm{C}$. The machine was calibrated prior to every experiment via direct infusion of the Agilent ESI-TOF low concentration tuning mixture, which provided an $\mathrm{m} / \mathrm{z}$ range of singly charged peaks up to $2700 \mathrm{Da}$ in both ion modes. Elemental analyses were performed by Atlantic Microlab Inc., Norcross, GA.

\section{Synthesis of the Ligands}

Both ligands L2 (N4Py ${ }^{2 \mathrm{Ar}_{2}} ; \mathrm{Ar}_{2}=-2,6$-difluoro-4-methoxyphenyl) and L3 (N4Py ${ }^{2 \mathrm{Ar}_{3}} \mathrm{Ar}_{3}$ $=-2,6$-difluoro- 3-methoxyphenyl) were prepared in a similar synthetic route shown in Scheme 2 .

Bis(6-(2,6-difluoro-4-methoxyphenyl)pyridin-2-yl)methanone-Amounts of bis(6bromopyridin-2-yl)methanone (1.2 g, $3.51 \mathrm{mmol}), 2,6$-difluoro-4-methoxyphenyl boronic acid $(1.45 \mathrm{~g}, 7.72 \mathrm{mmol})$, and XPhos-Pd-G2 $(166 \mathrm{mg}, 0.21 \mathrm{mmol})$ were taken in a Schlenk flask. The reagents were dissolved in degassed THF $(\sim 35 \mathrm{~mL})$. Degassed $0.5 \mathrm{M} \mathrm{K}_{3} \mathrm{PO}_{4}$ solution in $\mathrm{H}_{2} \mathrm{O}(28 \mathrm{~mL})$ was added to the stirring solution and the reaction allowed to continue for $72 \mathrm{~h}$ at $45^{\circ} \mathrm{C}$. After cooling the reaction to room temperature, the organic layer was extracted with $\mathrm{Et}_{2} \mathrm{O}$ and concentrated in vacuo. The product was purified by silica gel column chromatography using ethyl acetate/hexanes as eluent and was obtained as yellow solid (1.08 g, 66\%). ${ }^{1} \mathrm{H}$ NMR $\left(\mathrm{CDCl}_{3}\right) \delta 8.21(\mathrm{dd}, J=7.8,1.1 \mathrm{~Hz}, 2 \mathrm{H}), 7.94(\mathrm{t}, J=7.8 \mathrm{~Hz}$, $2 \mathrm{H}), 7.64-7.61(\mathrm{~m}, 2 \mathrm{H}), 6.54(\mathrm{~d}, J=9.8 \mathrm{~Hz}, 4 \mathrm{H}), 3.82(\mathrm{~s}, 6 \mathrm{H}) .{ }^{19} \mathrm{~F}$ NMR $\left(\mathrm{CDCl}_{3}, \mathrm{C}_{6} \mathrm{~F}_{6}\right.$ reference standard) $\delta-116.6$.

Bis(6-(2,6-difluoro-3-methoxyphenyl)pyridin-2-yl)methanone-After following the method for bis(6-(2,6-difluoro-4-methoxyphenyl)- pyridin-2-yl)methanone, utilizing 2,6difluoro-3-methoxyphenyl boronic acid as the reagent for the Suzuki-Miyaura coupling reaction, the ketone was isolated as yellow solid $(49 \%) .{ }^{1} \mathrm{H} \mathrm{NMR}\left(\mathrm{CDCl}_{3}\right) \delta 8.27(\mathrm{dd}, J=$ $7.9,1.0 \mathrm{~Hz}, 2 \mathrm{H}), 7.99$ (t, $J=7.8 \mathrm{~Hz}, 2 \mathrm{H}), 7.66$ (dd, $J=7.8,1.2 \mathrm{~Hz}, 2 \mathrm{H}), 7.01-6.89(\mathrm{~m}, 4 \mathrm{H})$, $3.90(\mathrm{~s}, 6 \mathrm{H}) .{ }^{19} \mathrm{~F} \mathrm{NMR}\left(\mathrm{CDCl}_{3}, \mathrm{C}_{6} \mathrm{~F}_{6}\right.$ reference standard) $\delta-128.0,-138.2$. 
Bis(6-(2,6-difluoro-4-methoxyphenyl)pyridin-2-yl)methanamine-Hydroxylamine hydrochloride $(0.24 \mathrm{~g}, 3.42 \mathrm{mmol})$ and sodium acetate $(0.28 \mathrm{~g}, 3.42 \mathrm{mmol})$ were dissolved in $\mathrm{H}_{2} \mathrm{O}(6 \mathrm{~mL})$ and stirred at $60^{\circ} \mathrm{C}$ for $1 \mathrm{~h}$ under ambient air conditions. Bis(6-(2,6difluoro-4- methoxyphenyl)pyridin-2-yl)methanone $(0.8 \mathrm{~g}, 1.71 \mathrm{mmol})$ was added to the solution followed by ethyl alcohol $(\sim 200 \mathrm{~mL})$. The reaction was stirred at $60{ }^{\circ} \mathrm{C}$ for $20 \mathrm{~h}$, at which time the temperature was raised to $80^{\circ} \mathrm{C}$. Amounts of ammonium acetate $(0.22 \mathrm{~g}$, $2.91 \mathrm{mmol})$ and ammonium hydroxide solution $(5.5 \mathrm{~mL}, 28-30 \%$ solution) were added. After $2 \mathrm{~h}$ of stirring, $\mathrm{Zn}$ dust $(0.50 \mathrm{~g}, 7.69 \mathrm{mmol})$ was added in portions over $10 \mathrm{~min}$. Stirring was continued for another $16 \mathrm{~h}$ at $80^{\circ} \mathrm{C}$. After cooling at room temperature, the solution was filtered through Celite. The filtrate was concentrated in vacuo. The residue was made basic by $\mathrm{NaOH}$ solution and extracted with $\mathrm{CH}_{2} \mathrm{Cl}_{2}$. The organic layer was dried over anhydrous $\mathrm{MgSO}_{4}$ and finally concentrated in vacuo to obtain bis(6-(2,6-difluoro-4methoxyphenyl)-pyridin-2-yl)methanamine as a pale brown-red solid $(0.69 \mathrm{~g}, 86 \%) .{ }^{1} \mathrm{H}$ NMR $\left(\mathrm{CDCl}_{3}\right) \delta 7.67(\mathrm{t}, J=7.8 \mathrm{~Hz}, 2 \mathrm{H}), 7.39(\mathrm{dd}, J=7.9,1.0 \mathrm{~Hz}, 2 \mathrm{H}), 7.31(\mathrm{dd}, J=7.8$, $1.3 \mathrm{~Hz}, 2 \mathrm{H}), 7.60-6.53(\mathrm{~m}, 4 \mathrm{H}), 5.44(\mathrm{~s}, 1 \mathrm{H}), 3.82(\mathrm{~s}, 6 \mathrm{H}), 2.76(\mathrm{~s}, 2 \mathrm{H})$.

Bis(6-(2,6-difluoro-3-methoxyphenyl)pyridin-2-yl)methanamine-Following the procedure described above, the compound was obtained as brown-orange solid in $96 \%$ yield. ${ }^{1} \mathrm{H}$ NMR $\left(\mathrm{CDCl}_{3}\right) \delta 7.72(\mathrm{t}, J=7.8 \mathrm{~Hz}, 2 \mathrm{H}), 7.45(\mathrm{dd}, J=7.9,1.0 \mathrm{~Hz}, 2 \mathrm{H}), 7.34(\mathrm{dd}, J$ $=7.7,1.2 \mathrm{~Hz}, 2 \mathrm{H}), 6.99-6.93(\mathrm{~m}, 4 \mathrm{H}), 5.47(\mathrm{~s}, 1 \mathrm{H}), 3.90(\mathrm{~s}, 6 \mathrm{H}), 2.48(\mathrm{~s}, 2 \mathrm{H})$.

Synthesis of N4Py2Ar2 (L2) and N4Py'Ar3 (L3)-Bis(6-(2,6-difluoro-4methoxyphenyl)pyridin-2-yl)methanamine $(0.14 \mathrm{~g}, 0.30 \mathrm{mmol})$ was taken in $\mathrm{CH}_{3} \mathrm{CN}$ (30 $\mathrm{mL})$ under ambient conditions. An amount of 2-bromomethylpyridine hydrobromide $(0.19$ $\mathrm{g}, 0.75 \mathrm{mmol})$ was added to the solution followed by $\mathrm{Cs}_{2} \mathrm{CO}_{3}(0.58 \mathrm{~g}, 1.79 \mathrm{mmol})$ and $\mathrm{NaI}$ $(0.13 \mathrm{~g}, 0.89 \mathrm{mmol})$. The reaction was stirred at $60{ }^{\circ} \mathrm{C}$ for $72 \mathrm{~h}$. The solution was filtered through Celite, and the filtrate was concentrated in vacuo. Ligand $\mathbf{L} 2$ was purified by column chromatography on basic alumina using ethyl acetate/hexanes and was obtained as a yellowishbrown solid (98 mg, 50\%). ${ }^{1} \mathrm{H}$ NMR $\left(\mathrm{CDCl}_{3}\right) \delta 8.44$ (ddd, $J=4.9,1.9,0.9 \mathrm{~Hz}$, 2H), $7.74(\mathrm{dt}, J=7.9,1.1 \mathrm{~Hz}, 2 \mathrm{H}), 7.67(\mathrm{t}, J=7.8 \mathrm{~Hz}, 2 \mathrm{H}), 7.59-7.50$ (m, 4H), 7.30 (dq, $J=$ 7.7, $1.3 \mathrm{~Hz}, 2 \mathrm{H}), 7.02$ (ddd, $J=7.5,4.9,1.2 \mathrm{~Hz}, 2 \mathrm{H}), 6.56-6.47(\mathrm{~m}, 4 \mathrm{H}), 5.45(\mathrm{~s}, 1 \mathrm{H}), 4.11$ $(\mathrm{s}, 4 \mathrm{H}), 3.79(\mathrm{~s}, 6 \mathrm{H}) .{ }^{19} \mathrm{~F} \mathrm{NMR}\left(\mathrm{CDCl}_{3}, \mathrm{C}_{6} \mathrm{~F}_{6}\right.$ reference standard) $\delta-116.4$. FAB-MS for $[\mathbf{L 2}+\mathrm{H}]^{+}$observed $\mathrm{m} / \mathrm{z}$ 652.23353, calcd $\mathrm{m} / \mathrm{z}$ 652.23356.

Ligand N4Py ${ }^{2 \mathrm{Ar} 3}$ ( $\left.\mathbf{L 3}\right)$ was prepared in the same way as $\mathbf{L} 2$ by alkylating bis(6-(2,6difluoro-3-methoxyphenyl)pyridin-2-yl)-methanamine (0.65 g, $1.38 \mathrm{mmol})$ and was obtained as a yellow solid (60\%). ${ }^{1} \mathrm{H}$ NMR $\left(\mathrm{CDCl}_{3}\right) \delta 8.44(\mathrm{ddd}, J=4.9,1.9,0.9 \mathrm{~Hz}, 2 \mathrm{H})$, 7.74-7.61 (m, 6H), $7.51(\mathrm{td}, J=7.7,1.8 \mathrm{~Hz}, 2 \mathrm{H}), 7.33(\mathrm{dq}, J=7.3,1.3 \mathrm{~Hz}, 2 \mathrm{H}), 7.01$ (ddd, $J$ $=7.5,4.9,1.2 \mathrm{~Hz}, 2 \mathrm{H}), 6.92-6.80(\mathrm{~m}, 4 \mathrm{H}), 5.50(\mathrm{~s}, 1 \mathrm{H}), 4.14(\mathrm{~s}, 4 \mathrm{H}), 3.81(\mathrm{~s}, 6 \mathrm{H}) .{ }^{19} \mathrm{~F} \mathrm{NMR}$ $\left(\mathrm{CDCl}_{3}, \mathrm{C}_{6} \mathrm{~F}_{6}\right.$ reference standard) $\delta-127.6,-138.1$. FAB-MS for $[\mathbf{L 3}+\mathrm{H}]^{+}$observed $\mathrm{m} / z$ 652.23399, calcd $\mathrm{m} / \mathrm{z} 652.23356$.

\section{Synthesis of 2 and 3}

An amount of N4Py $2 \mathrm{Ar}_{2}(\mathbf{L} 2,150 \mathrm{mg}, 0.23 \mathrm{mmol})$ was dissolved in $\mathrm{CH}_{3} \mathrm{CN}(10 \mathrm{~mL})$, and $\mathrm{Fe}\left(\mathrm{ClO}_{4}\right)_{2} \cdot 6 \mathrm{H}_{2} \mathrm{O}(84 \mathrm{mg}, 0.23 \mathrm{mmol})$ was added. The reaction was stirred for $3 \mathrm{~h}$, and the 
solvent was removed in vacuo. The residue was redissolved in $\mathrm{CH}_{3} \mathrm{CN}(4 \mathrm{~mL})$ and filtered through Celite. Vapor diffusion of $\mathrm{Et}_{2} \mathrm{O}$ into the $\mathrm{CH}_{3} \mathrm{CN}$ solution yielded dark brown-red crystals of $\left[\mathrm{Fe}^{\mathrm{II}}\left(\mathrm{N} 4 \mathrm{Py}^{2 \mathrm{Ar}_{2}}\right)\left(\mathrm{CH}_{3} \mathrm{CN}\right)\right]\left(\mathrm{ClO}_{4}\right)_{2}$ (2) along with some brown-red precipitate. The crystals were collected, and a second crystallization $\left(\mathrm{CH}_{3} \mathrm{CN} / \mathrm{Et}_{2} \mathrm{O}\right)$ was performed with the precipitate. A second batch of crystals of 2 was obtained in a few days. Combined yield: $140 \mathrm{mg}(71 \%)$. UV-vis $\left(\mathrm{CH}_{3} \mathrm{CN}, 23^{\circ} \mathrm{C}\right) \lambda_{\max } 460 \mathrm{~nm}\left(\varepsilon=2420 \mathrm{M}^{-1} \mathrm{~cm}^{-1}\right), 370 \mathrm{~nm}(\varepsilon=$ $3260 \mathrm{M}^{-1} \mathrm{~cm}^{-1}$ ). ESI-MS observed $\mathrm{m} / \mathrm{z} 353.5795$ (calcd $\mathrm{m} / \mathrm{z}$ for $\left.\left[\mathrm{Fe}\left(\mathrm{N} 4 \mathrm{Py}^{2 \mathrm{Ar}}\right)\right]^{2+} 353.5798\right) .{ }^{1} \mathrm{H}$ NMR $\left(\mathrm{CD}_{3} \mathrm{CN}\right.$, TMS reference standard) $\delta 100.3,80.8$, $64.8,38.5,37.1,36.4,30.2,22.4,6.7,6.0,4.7,3.8,2.1,-1.4$.

Complex $\left[\mathrm{Fe}^{\mathrm{II}}\left(\mathrm{N} 4 \mathrm{Py}^{2 \mathrm{Ar}}\right)\left(\mathrm{CH}_{3} \mathrm{CN}\right)\right]\left(\mathrm{ClO}_{4}\right)_{2}(3)$ was prepared via a method similar to that used to obtain 2, using N4Py ${ }^{2 \mathrm{Ar}} 3(\mathbf{L 3}, 250 \mathrm{mg}, 0.38 \mathrm{mmol})$ and $\mathrm{Fe}\left(\mathrm{ClO}_{4}\right)_{2} \cdot 6 \mathrm{H}_{2} \mathrm{O}(140 \mathrm{mg}$, $0.38 \mathrm{mmol}$ ). Complex 3 was obtained as a brown-red powder $(260 \mathrm{mg}, 72 \%)$. UV-vis $\left(\mathrm{CH}_{3} \mathrm{CN}, 23{ }^{\circ} \mathrm{C}\right) \lambda_{\max } 460 \mathrm{~nm}\left(\varepsilon=2330 \mathrm{M}^{-1} \mathrm{~cm}^{-1}\right), 373 \mathrm{~nm}\left(\varepsilon=2850 \mathrm{M}^{-1} \mathrm{~cm}^{-1}\right)$. ESI-MS observed $\mathrm{m} / z 353.5798$ (calcd $\mathrm{m} / \mathrm{z}$ for $\left.\left[\mathrm{Fe}\left(\mathrm{N} 4 \mathrm{Py}^{2 \mathrm{Ar}} 3\right)\right]^{2+} 353.5798\right) .{ }^{1} \mathrm{H} \mathrm{NMR}\left(\mathrm{CD}_{3} \mathrm{CN}\right.$, TMS reference standard) $\delta 74.8,60.5,49.0,30.8,29.5,28.8,24.2,18.4,8.1,8.0,5.0,4.6$, $4.1,2.7,2.1,1.8$.

\section{$\left[\mathrm{Fe}^{\mathrm{Il}}\left(\mathrm{N} 4 \mathrm{Py}^{2 \mathrm{Ar}}{ }^{1}\right)(\mathrm{OH})\right]\left(\mathrm{ClO}_{4}\right)(4)$}

$\mathrm{Fe}^{\mathrm{II}}$ complex $\left[\mathrm{Fe}^{\mathrm{II}}\left(\mathrm{N} 4 \mathrm{Py}^{2 \mathrm{Ar}}\right)-\left(\mathrm{CH}_{3} \mathrm{CN}\right)\right]\left(\mathrm{ClO}_{4}\right)_{2}(87.7 \mathrm{mg} ; 0.099 \mathrm{mmol})$ was dissolved in $\mathrm{CH}_{2} \mathrm{Cl}_{2}(4 \mathrm{~mL}$ ), and $\mathrm{NaOH}$ (aqueous, $79 \mu \mathrm{L}, 20 \% \mathrm{w} / \mathrm{v}$ ) was added under Ar atmosphere. The reaction mixture was stirred for $1 \mathrm{~h}$, and the color of the solution changed from pale yellow to dark red. The volatiles were removed in vacuo, and the red residue was redissolved in $\mathrm{CH}_{2} \mathrm{Cl}_{2}(3 \mathrm{~mL})$. The solution was filtered through Celite, and layering of pentane over the $\mathrm{CH}_{2} \mathrm{Cl}_{2}$ solution yielded red crystals of $\left[\mathrm{Fe}^{\mathrm{II}}\left(\mathrm{N} 4 \mathrm{Py}^{2 \mathrm{Ar}} 1\right)(\mathrm{OH})\right]\left(\mathrm{ClO}_{4}\right) \cdot \mathrm{H}_{2} \mathrm{O}\left(\mathbf{4} \cdot \mathbf{H}_{2} \mathbf{O}, 47 \mathrm{mg}\right.$, $61 \%) .{ }^{1} \mathrm{H}$ NMR $\left(\mathrm{CD}_{2} \mathrm{Cl}_{2}\right.$, TMS reference standard) $\delta 153.7,98.9,58.6,54.0,45.7,44.8$, 34.6, 31.0, 30.5, 27.0, 25.0, 8.2. UV-vis $\left(\mathrm{CH}_{2} \mathrm{Cl}_{2}\right.$ under $\left.\mathrm{N}_{2}\right) \lambda_{\max }=436 \mathrm{~nm}, 538 \mathrm{~nm}$. Elemental Anal. (calcd for $\mathrm{C}_{35} \mathrm{H}_{28} \mathrm{ClO}_{6} \mathrm{~F}_{4} \mathrm{FeN}_{5}, \mathbf{4} \cdot \mathrm{H}_{2} \mathrm{O}$ ) C, 53.76, H, 3.61, N, 8.96; found: C, 53.66, H, 3.55, N, 8.92.

\section{Generation of 2-O and 3-O: UV-Vis Spectroscopy}

An amount of complex 2 or $\mathbf{3}$ in $\mathrm{CH}_{3} \mathrm{CN}(1.04 \mathrm{mM}$ for $\mathbf{2}$ and $0.99 \mathrm{mM}$ for $\mathbf{3}$ ) was taken in a custom-made Schlenk flask fitted with a UV-vis dip-probe. The setup was cooled to $-20{ }^{\circ} \mathrm{C}$ $\left(-35{ }^{\circ} \mathrm{C}\right.$ for 3$)$. After recording the initial UV-vis spectrum for the starting $\mathrm{Fe}^{\mathrm{II}}$ complex, IBX-ester (1.5 equiv for $\mathbf{2}$ and 3.0 equiv for $\mathbf{3}$ ) was added to the solution, and the changes in the UV-vis spectra were recorded.

\section{Freeze-Quench Mössbauer for 3 + IBX-ester}

Freeze-quenching of ${ }^{57} \mathrm{Fe}$-enriched samples of $\mathbf{3}$ was carried out using a custom quench system. Samples of $\mathbf{3}$ dissolved in acetonitrile $\left(7.5 \mathrm{mM}\right.$ in $\left.{ }^{57} \mathrm{Fe}\right)$ were mixed anaerobically with IBX-ester (75 $\mathrm{mM}$ in acetonitrile) using gas-tight Hamilton syringes with 2:1 mixing in order that the complexes had a final concentration of $5 \mathrm{mM}$. IBX-ester (5 equiv) was mixed with complex $\mathbf{3}$ at $-5{ }^{\circ} \mathrm{C}$. The reaction temperature was kept constant using a DC10-K10 Haake water circulator. Samples were manually ejected and frozen in an 2-methylbutane bath kept below $-135{ }^{\circ} \mathrm{C}$ using liquid nitrogen. 


\section{Kinetic Studies}

Rate Constant for 2-O to 2-OAr $\left(\mathbf{k}_{\mathbf{2}}\right)$ - In a typical experiment, reaction of IBX-ester with complex 2 in $\mathrm{CH}_{3} \mathrm{CN}$ was followed by UV-vis spectroscopy. Addition of IBX-ester resulted in rapid decay of the $\mathrm{Fe}^{\mathrm{II}}$ peaks (370 and $460 \mathrm{~nm}$ ) along with the concomitant formation of the $\mathrm{Fe}^{\mathrm{IV}}(\mathrm{O})$ species 2-O $(750 \mathrm{~nm})$. The kinetics of the reaction was followed after the full conversion of the $750 \mathrm{~nm}$ peak $(t=0)$. The $750 \mathrm{~nm}$ peak was subsequently converted into a more intense peak at $780 \mathrm{~nm}$, corresponding to 2-OAr. The absorbance at $780 \mathrm{~nm}$ was plotted versus time, and the fitting of the data with the first-order rate equation $\left(\mathrm{Abs}_{t}=\mathrm{Abs}_{\mathrm{f}}+\left(\mathrm{Abs}_{0}-\mathrm{Abs}_{\mathrm{f}}\right) \exp (-k t) ; \mathrm{Abs}_{t}=\right.$ absorbance at time $t ; \mathrm{Abs}_{\mathrm{f}}=$ final absorbance at the end of the reaction; $\mathrm{Abs}_{0}=$ initial absorbance at $\left.t=0\right)$ provided the rate constant $\left(k_{2}\right)$ for the $\mathrm{C}-\mathrm{F}$ hydroxylation reaction.

Rate Constant for 3-0 to 3-OAr $\left(\mathbf{k}_{\mathbf{3}}\right)$-In a single-mixing experiment, complex $\mathbf{3}$ in $\mathrm{CH}_{3} \mathrm{CN}$ was reacted with IBX-ester (5 equiv), taken in $\mathrm{CH}_{3} \mathrm{CN}$ at $22{ }^{\circ} \mathrm{C}$. Complete decay of the $\mathrm{Fe}^{\mathrm{II}}$ peak $(460 \mathrm{~nm})$ and the formation of the $\mathrm{Fe}^{\mathrm{IV}}(\mathrm{O})(755 \mathrm{~nm})$ was observed within 0.75 s. Subsequent formation of the $915 \mathrm{~nm}$ peak (corresponding to 3-OAr) was plotted versus time and fitted with first-order rate equation $\left(\mathrm{Abs}_{t}=\mathrm{Abs}_{\mathrm{f}}+\left(\mathrm{Abs}_{0}-\mathrm{Abs}_{\mathrm{f}}\right) \exp (-k t)\right)$ to obtain the rate constant $\left(k_{3}\right)$.

\section{X-ray Crystallography}

All reflection intensities were measured at 110(2) K using a SuperNova diffractometer (equipped with Atlas detector) with $\mathrm{Cu} \mathrm{Ka}$ radiation $(\lambda=1.54178 \AA$ ) under the program CrysAlisPro (Version 1.171.36.32 Agilent Technologies, 2013). The program CrysAlisPro (Version 1.171.36.32 Agilent Technologies, 2013) was used to refine the cell dimensions and for data reduction. The structure was solved with the program SHELXS-2013 (Sheldrick, 2013) and was refined on $F_{2}$ with SHELXL-2013 (Sheldrick, 2013). Analytical numeric absorption corrections based on a multifaceted crystal model were applied using CrysAlisPro (Version 1.171.36.32 or 1.171.37.27t, Agilent Technologies, 2013). The temperature of the data collection was controlled using the system Cryojet (manufactured by Oxford Instruments). The $\mathrm{H}$ atoms were placed at calculated positions (unless otherwise specified) using the instructions AFIX 13, AFIX 23, AFIX 43, or AFIX 137 with isotropic displacement parameters having values 1.2 or 1.5 times $U_{\text {eq }}$ of the attached C atoms. For 1$\mathbf{O}$, the coordinates of the $\mathrm{H}$ atoms attached to $\mathrm{C} 1 \mathrm{~S}$ (from $\mathrm{CH}_{3} \mathrm{CN}$ ) were refined freely, and the $\mathrm{C}-\mathrm{H}$ bonds were restrained to be 0.98 (3) $\AA$ using the DFIX instruction. For 4, the $\mathrm{H}$ atoms attached to $\mathrm{O} 1 \mathrm{~A} / \mathrm{O} 1 \mathrm{~B}$ (coordinated $\mathrm{OH}^{-}$) and $\mathrm{O} 1 \mathrm{~W} / \mathrm{O} 2 \mathrm{~W}$ (lattice water molecules) were approximately located from difference Fourier maps, and the coordinates were refined freely. The $\mathrm{O}-\mathrm{H}$ and $\mathrm{H} \cdot \cdots \mathrm{H}$ distances (water molecules only) were restrained within reasonable ranges using the DFIX instructions.

$\left[\mathrm{Fe}^{\mathrm{IV}}(\mathbf{O})\left(\mathrm{N}_{4} \mathrm{Py}^{2 \mathrm{Ar}_{1}}\right)\right]\left(\mathrm{BF}_{\mathbf{4}}\right)_{\mathbf{2}}(\mathbf{1 - 0})$-Before the last set of refinement cycles, the occupancy factor for $\mathrm{O} 1$ was refined freely using a free variable. Its refined value was $1.009(6)$, which proves that the $\mathrm{O}^{2-}$ site is fully occupied. In the final refinement, the occupancy factor for $\mathrm{O} 1$ was set to 1 . The Fe1-O1 distance refines to 1.6600(16). The structure is mostly ordered. However, one of the two crystallographically Independent $\mathrm{BF}_{4}{ }^{-}$ counterions is found to be disordered over two orientations, and the occupancy factor of the 
major component of the disorder refines to $0.565(9)$. Chemical formula $=$ $\mathrm{C}_{35} \mathrm{H}_{25} \mathrm{~F}_{4} \mathrm{FeN}{ }_{5} \mathrm{O} \cdot 2\left(\mathrm{BF}_{4}\right) \cdot \mathrm{C}_{2} \mathrm{H}_{3} \mathrm{~N}, F_{\mathrm{W}}=878.12$, small yellow block, crystal size $=0.092 \times$ $0.050 \times 0.045 \mathrm{~mm}^{3}$, monoclinic, $P 2_{1} / c$ (no. 14), $a=11.7881(2), b=16.3973(2)$, and $c=$ 19.7780(3) ̊, $\beta=105.5388(18)^{\circ}, V=3683.22(10) \AA^{3}, Z=4, D_{X}=1.584 \mathrm{~g} \mathrm{~cm}^{-3}, \mu=4.208$ $\mathrm{mm}^{-1}, T_{\min }-T_{\max }: 0.736-0.863$. A total of 47739 reflections were measured up to a resolution of $(\sin \theta / \lambda)_{\max }=0.62 \AA^{-1}$. A total of 7232 reflections were unique $\left(R_{\text {int }}=\right.$ 0.0584 ), of which 6017 were observed [ $I>2 \sigma(I)]$. A total of 581 parameters were refined using 151 restraints. $R 1 / W R 2$ [I> $2 \sigma(I)$ ]: 0.0379/0.0907. $R 1 / w R 2$ [all refln]: 0.0499/0.0978. $S=1.024$. Residual electron density was found to be between -0.44 and $0.62 e \AA^{-3}$.

[Fe"ll(N4Py $\left.\left.{ }^{2 \mathrm{Ar}_{1}}\right)\left(\mathrm{CH}_{3} \mathrm{CN}\right)\right]\left(\mathrm{ClO}_{4}\right)_{2}(\mathbf{2})$-The structure is mostly ordered. The two crystallographically independent $\mathrm{ClO}_{4}{ }^{-}$counterions are found to be disordered over two orientations, and the occupancy factors of the major components of the disorder refine to 0.54(5) and 0.588(19). Chemical formula $=\mathrm{C}_{39} \mathrm{H}_{32} \mathrm{~F}_{4} \mathrm{FeN}_{6} \mathrm{O}_{2} \cdot 2\left(\mathrm{ClO}_{4}\right), F_{\mathrm{W}}=947.45$, orange-red lath, crystal size $=0.39 \times 0.13 \times 0.05 \mathrm{~mm}^{3}$, monoclinic, $P 2_{1} / n$ (no. 14), $a=$ 12.6196(3), $b=20.6085(5)$, and $c=14.9361(3) \AA, \beta=96.679(2)^{\circ}, V=3858.08(15) \AA^{3}, Z=$ $4, D_{X}=1.631 \mathrm{~g} \mathrm{~cm}^{-3}, \mu=5.192 \mathrm{~mm}^{-1}, T_{\min }-T_{\max }: 0.290-0.823$. A total of 25214 reflections were measured up to a resolution of $(\sin \theta / \lambda)_{\max }=0.62 \AA^{-1}$. A total of 7568 reflections were unique $\left(R_{\text {int }}=0.0445\right)$, of which 6270 were observed $[I>2 \sigma(I)]$. A total of 636 parameters were refined using 278 restraints. $R 1 / w R 2[I>2 \sigma(I)]: 0.0393 / 0.0939$. $R 1 / w R 2$ [all refln]: $0.0521 / 0.1022 . S=1.014$. Residual electron density was found to be between -0.40 and $0.49 e \AA^{-3}$.

[Fe $\left.{ }^{\text {IIII }}\left(\mathrm{N}_{4} \mathrm{Py}^{\mathrm{Ar}}{ }_{2}, \mathrm{Ar}_{2} \mathrm{O}\right)\right]\left(\mathrm{ClO}_{4}\right)_{\mathbf{2}}(\mathbf{2}-\mathrm{OAr})$ - The structure is significantly disordered (except for the Fe complex which is ordered). All perchlorate counterions are found to be significantly disordered as they are found at special positions, i.e., at sites of either mirror or 2 -fold axial symmetries. The sum of all occupancies factors of the components of the disorder is restrained to be 2 using the SUMP instruction. The two methoxy groups of the Fe complex are also disordered over two orientations, and the occupancy factors of the major components of the disordered refine to 0.791(9) and 0.545(10). One lattice $\mathrm{CH}_{3} \mathrm{CN}$ solvent molecule is found at sites of 2-fold axial symmetry, and its occupancy must be 0.5 . The crystal lattice also contains some unresolved residual electron density, which most likely corresponds to some heavily disordered lattice solvent molecules. Their contribution has been taken out in the final refinement (SQUEEZE details are provided in the CIF file, Spek, 2009). Chemical formula $=\left(\mathrm{C}_{37} \mathrm{H}_{29} \mathrm{~F}_{3} \mathrm{FeN}_{5} \mathrm{O}_{3}\right) \cdot 2\left(\mathrm{ClO}_{4}\right) \cdot 0.5 \mathrm{C}_{2} \mathrm{H}_{3} \mathrm{~N}, F_{\mathrm{w}}=923.93$, crystal size $=0.23 \times 0.18 \times 0.13 \mathrm{~mm}^{3}$, monoclinic, $L / \mathrm{m}, a=11.6550(2), b=26.4005(6)$, and $c=$ 28.4632 (5) $\AA, \beta=91.2677(15)^{\circ}, V=8755.9$ (3) $\AA^{3}, Z=4, D_{X}=1.402 \mathrm{~g} \mathrm{~cm}^{-3}, \mu=4.54$ $\mathrm{mm}^{-1}, T_{\min }-T_{\max }: 0.527^{-} 0.690$. A total of 36960 reflections were measured up to a resolution of $(\sin \theta / \lambda)_{\max }=0.616 \AA^{-1}$. A total of 8791 reflections were unique $\left(R_{\mathrm{int}}=\right.$ $0.041)$, of which 7375 were observed $[I>2 \sigma(I)]$. A total of 934 parameters were refined using 1531 restraints. $R 1 / W R 2$ [I> $2 \sigma(I)$ ]: 0.0576/0.1669. $R 1 / W R 2$ [all refln]:

$0.0679 / 0.1771 . S=1.03$ e $\AA^{-3}$.

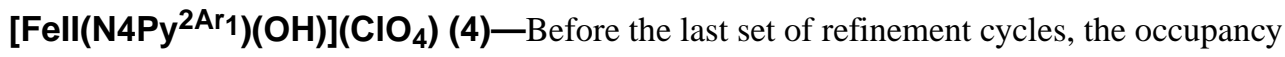
factors for $\mathrm{O} 1 \mathrm{~A}$ and $\mathrm{O} 1 \mathrm{~B}$ were refined freely as $\mathrm{O}$ atoms using free variables, and their 
refined values were $0.960(12)$ and $1.052(12)$. When refined as $\mathrm{F}$ atoms, their refined values were $0.797(10)$ and $0.875(10)$. Consequently, the sites O1A and O1B are unambiguously occupied by coordinated $\mathrm{OH}^{-}$and not $\mathrm{F}^{-}$. In the final refinement, the occupancy factors for $\mathrm{O} 1 \mathrm{~A}$ and $\mathrm{OAB}$ were set to 1 . The structure is mostly ordered. The two crystallographically independent perchlorate counterions are found to be disordered over two or three orientations (all occupancy factors are provided in the CIF file). The crystal that was mounted on the diffractometer was non-merohedrally twinned, and the two twin components are related by a 2 -fold axis along the direct space vector $\left[\begin{array}{lll}1 & 0 & 0\end{array}\right]$. The BASF scale factor refines to $0.4628(11)$. The structure was solved and refined in the noncentrosymmetric space group $P 2_{1}$. The absolute configuration was established by anomalous-dispersion effects in diffraction measurements on the crystal. The Flack parameter refines to $-0.005(2)$. Chemical formula $=\mathrm{C}_{35} \mathrm{H}_{26} \mathrm{~F}_{4} \mathrm{FeN}{ }_{5} \mathrm{O} \cdot \mathrm{ClO}_{4} \cdot \mathrm{H}_{2} \mathrm{O}, F_{\mathrm{W}}=781.92$, dark red block, crystal size $=0.38 \times$ $0.34 \times 0.19 \mathrm{~mm}^{3}$, monoclinic, $P 2_{1}$ (no. 4), $a=14.4312$ (4), $b=12.8954$ (3), and $c=$ 18.3009(5) $\AA, \beta=92.161(2)^{\circ}, V=3403.30(15) \AA^{3}, Z=4, D_{X}=1.526 \mathrm{~g} \mathrm{~cm}^{-3}, \mu=4.946$ $\mathrm{mm}^{-1}$, abs. corr. range: $0.255-0.511$. A total of 22245 reflections were measured up to a resolution of $(\sin \theta / \lambda)_{\max }=0.62 \AA^{-1}$. A total of 12531 reflections were unique $\left(R_{\text {int }}=\right.$ $0.0165)$, of which 12165 were observed $[I>2 \sigma(I)]$. A total of 1077 parameters were refined using 584 restraints. $R 1 / w R 2$ [ $I>2 \sigma(I)$ ]: 0.0332/0.0904. $R 1 / w R 2$ [all refln]: 0.0340/0.0909. $S=1.018$. Residual electron density was found to be between -0.37 and $0.85 e \AA^{-3}$.

\section{Computations}

All computations were carried out using ORCA version 3.0.2. ${ }^{56}$ Geometry optimization of the ferryl complex was begun from the crystal structure coordinates and employed the BP86 functional ${ }^{57,58}$ and def2-TZVP basis set ${ }^{59}$ on all atoms except Fe, which had the expanded $\mathrm{CP}(\mathrm{PPP})$ basis set ${ }^{60}$ and an increased integration accuracy. Solvation was simulated using the conductorlike screening model (COSMO $)^{61}$ in an infinite dielectric, while dispersion corrections were included using Grimme's correction. ${ }^{62}$ Spectroscopic parameters were calculated using these optimized coordinates. Isomer shift and quadrupole splitting parameters were calculated at the same level of theory using a calibration procedure similar to that reported in ref 63 (see Supporting Information for additional details), while hyperfine coupling tensors were calculated as described previously. ${ }^{63}$ Optimized coordinates and sample input files for all calculations are included in the Supporting Information.

\section{Supplementary Material}

Refer to Web version on PubMed Central for supplementary material.

\section{Acknowledgments}

The NIH (D.P.G., GM62309 and GM119374) is acknowledged for financial support. We are grateful to Prof. Kenneth Karlin (JHU) for the access to stopped-flow UV-vis and low-temperature $\left(-70^{\circ} \mathrm{C}\right)$ freezer. I.I.-B. and M.D. gratefully acknowledge support through the "Solar Technologies Go Hybrid" initiative of the State of Bavaria.

\section{References}

1. Bruijnincx PCA, van Koten G, Klein Gebbink RJM. Chem Soc Rev. 2008; 37:2716-2744. [PubMed: 19020684] 
2. Fitzpatrick PF. Biochemistry. 2003; 42:14083-14091. [PubMed: 14640675]

3. Kovaleva EG, Lipscomb JD. Nat Chem Biol. 2008; 4:186-193. [PubMed: 18277980]

4. Eser BE, Barr EW, Frantom PA, Saleh L, Bollinger JM Jr, Krebs C, Fitzpatrick PF. J Am Chem Soc. 2007; 129:11334-11335. [PubMed: 17715926]

5. Panay AJ, Lee M, Krebs C, Bollinger JM Jr, Fitzpatrick PF. Biochemistry. 2011; 50:1928-1933. [PubMed: 21261288]

6. Ansari A, Kaushik A, Rajaraman G. J Am Chem Soc. 2013; 135:4235-4249. [PubMed: 23373840]

7. de Visser SP, Oh K, Han AR, Nam W. Inorg Chem. 2007; 46:4632-4641. [PubMed: 17444641]

8. Hegg EL, Ho RYN, Que L Jr. J Am Chem Soc. 1999; 121:1972-1073.

9. Jensen MP, Lange SJ, Mehn MP, Que EL, Que L Jr. J Am Chem Soc. 2003; 125:2113-2128. [PubMed: 12590539]

10. Makhlynets OV, Rybak-Akimova EV. Chem - Eur J. 2010; 16:13995-14006. [PubMed: 21117047]

11. Mehn MP, Fujisawa K, Hegg EL, Que L Jr. J Am Chem Soc. 2003; 125:7828-7842. [PubMed: 12823001]

12. Mekmouche Y, Ménage S, Toia-Duboc C, Fontecave M, Galey JB, Lebrun C, Pécaut J. Angew Chem, Int Ed. 2001; 40:949-952.

13. Nielsen A, Larsen FB, Bond AD, McKenzie CJ. Angew Chem, Int Ed. 2006; 45:1602-1606.

14. Oh NY, Seo MS, Lim MH, Consugar MB, Park MJ, Rohde JU, Han J, Kim KM, Kim J, Que L Jr, Nam W. Chem Commun. 2005; 5644-5646

15. Sahu S, Widger LR, Quesne MG, de Visser SP, Matsumura H, Moënne-Loccoz P, Siegler MA, Goldberg DPJ. Am Chem Soc. 2013; 135:10590-10593.

16. Thibon A, Jollet V, Ribal C, Sénéchal-David K, Billon L, Sorokin AB, Banse F. Chem - Eur J. 2012; 18:2715-2724. [PubMed: 22290835]

17. Makhlynets OV, Das P, Taktak S, Flook M, Mas-Balleste R, Rybak-Akimova EV, Que L Jr. Chem Eur J. 2009; 15:13171-13180. [PubMed: 19876966]

18. Harman WH, Chang CJ. J Am Chem Soc. 2007; 129:15128-15129. [PubMed: 18004860]

19. Jensen MP, Mehn MP, Que L Jr. Angew Chem, Int Ed. 2003; 42:4357-4360.

20. de Ruiter G, Thompson NB, Takase MK, Agapie T. J Am Chem Soc. 2016; 138:1486-1489. [PubMed: 26760217]

21. de Visser SP. J Am Chem Soc. 2006; 128:15809-15818. [PubMed: 17147391]

22. de Visser SP. J Am Chem Soc. 2006; 128:9813-9824. [PubMed: 16866538]

23. Geng CY, Ye SF, Neese F. Angew Chem, Int Ed. 2010; 49:5717-5720.

24. Neidig ML, Decker A, Choroba OW, Huang F, Kavana M, Moran GR, Spencer JB, Solomon EI. Proc Natl Acad Sci U S A. 2006; 103:12966-12973. [PubMed: 16920789]

25. Srnec M, Wong SD, England J, Que L Jr, Solomon EI. Proc Natl Acad Sci U S A. 2012; 109:14326-14331. [PubMed: 22908238]

26. Wilson SA, Chen J, Hong S, Lee YM, Clémancey M, Garcia-Serres R, Nomura T, Ogura T, Latour JM, Hedman B, Hodgson KO, Nam W, Solomon EI. J Am Chem Soc. 2012; 134:11791-11806. [PubMed: 22708532]

27. Wong SD, Bell CB III, Liu LV, Kwak Y, England J, Alp EE, Zhao J, Que L Jr, Solomon EI. Angew Chem, Int Ed. 2011; 50:3215-3218.

28. Hirao H, Kumar D, Que L Jr, Shaik S. J Am Chem Soc. 2006; 128:8590-8606. [PubMed: 16802826]

29. Bollinger, JM., Jr, Chang, W-c, Matthews, ML., Martinie, RJ., Boal, AK., Krebs, C. 2Oxoglutarate-Dependent Oxygenases. The Royal Society of Chemistry; London: 2015. p. 95-122.

30. Krebs C, Galonić Fujimori DG, Walsh CT, Bollinger JM Jr. Acc Chem Res. 2007; 40:484-492. [PubMed: 17542550]

31. Bigi JP, Harman WH, Lassalle-Kaiser B, Robles DM, Stich TA, Yano J, Britt RD, Chang CJ. J Am Chem Soc. 2012; 134:1536-1542. [PubMed: 22214221]

32. McDonald AR, Guo Y, Vu VV, Bominaar EL, Münck E, Que L Jr. Chem Sci. 2012; 3:1680-1693. [PubMed: 23267430] 
33. Sahu S, Quesne MG, Davies CG, Dürr M, Ivanović-Burmazović I, Siegler MA, Jameson GNL, de Visser SP, Goldberg DP. J Am Chem Soc. 2014; 136:13542-13545. [PubMed: 25246108]

34. Puri M, Biswas AN, Fan R, Guo Y, Que L Jr. J Am Chem Soc. 2016; 138:2484-2487. [PubMed: 26875530]

35. Biswas AN, Puri M, Meier KK, Oloo WN, Rohde GT, Bominaar EL, Münck E, Que L Jr. J Am Chem Soc. 2015; 137:2428-2431. [PubMed: 25674662]

36. McDonald AR, Que L Jr. Coord Chem Rev. 2013; 257:414-428.

37. Pearson DM, Conley NR, Waymouth RM. Organometallics. 2011; 30:1445-1453.

38. Terrier, F. Modern Nucleophilic Aromatic Substitution. Wiley- VCH Verlag GmbH \& Co. KGaA; Weinheim, Germany: 2013.

39. England J, Guo Y, Farquhar ER, Young VG Jr, Münck E, Que L Jr. J Am Chem Soc. 2010; 132:8635-8644. [PubMed: 20568768]

40. Klinker EJ, Kaizer J, Brennessel WW, Woodrum NL, Cramer CJ, Que L Jr. Angew Chem, Int Ed. 2005; 44:3690-3694.

41. Lacy DC, Gupta R, Stone KL, Greaves J, Ziller JW, Hendrich MP, Borovik AS. J Am Chem Soc. 2010; 132:12188-12190. [PubMed: 20704272]

42. Meyer S, Klawitter I, Demeshko S, Bill E, Meyer F. Angew Chem, Int Ed. 2013; 52:901-905.

43. Rohde JU, In JH, Lim MH, Brennessel WW, Bukowski MR, Stubna A, Münck E, Nam W, Que L Jr. Science. 2003; 299:1037-1039. [PubMed: 12586936]

44. Thibon A, England J, Martinho M, Young VG Jr, Frisch JR, Guillot R, Girerd JJ, Münck E, Que L Jr, Banse F. Angew Chem, Int Ed. 2008; 47:7064-7067.

45. Prakash J, Rohde GT, Meier KK, Münck E, Que L Jr. Inorg Chem. 2015; 54:11055-11057. [PubMed: 26615667]

46. Neese F. J Inorg Biochem. 2006; 100:716-726. [PubMed: 16504299]

47. Lim MH, Rohde JU, Stubna A, Bukowski MR, Costas M, Ho RY, Münck E, Nam W, Que L Jr. Proc Natl Acad Sci U S A. 2003; 100:3665-3670. [PubMed: 12644707]

48. Prat I, Company A, Corona T, Parella T, Ribas X, Costas M. Inorg Chem. 2013; 52:9229-9244. [PubMed: 23901826]

49. Ye W, Ho DM, Friedle S, Palluccio TD, Rybak-Akimova EV. Inorg Chem. 2012; 51:5006-5021. [PubMed: 22534174]

50. Ye W, Staples RJ, Rybak-Akimova EV. J Inorg Biochem. 2012; 115:1-12. [PubMed: 22922287]

51. Soo HS, Komor AC, Iavarone AT, Chang CJ. Inorg Chem. 2009; 48:10024-10035. [PubMed: 19780564]

52. Ogo S, Yamahara R, Roach M, Suenobu T, Aki M, Ogura T, Kitagawa T, Masuda H, Fukuzumi S, Watanabe Y. Inorg Chem. 2002; 41:5513-5520. [PubMed: 12377047]

53. Benisvy L, Halut S, Donnadieu B, Tuchagues JP, Chottard JC, Li Y. Inorg Chem. 2006; 45:24032405. [PubMed: 16529458]

54. Nierengarten H, Rojo J, Leize E, Lehn JM, Van Dorsselaer A. Eur J Inorg Chem. 2002; 2002:573579.

55. Zhdankin VV, Koposov AY, Litvinov DN, Ferguson MJ, McDonald R, Luu T, Tykwinski RR. J Org Chem. 2005; 70:6484-6491. [PubMed: 16050713]

56. Neese F. Wiley Interdisciplinary Reviews: Computational Molecular Science. 2012; 2:73-78.

57. Becke AD. Phys Rev A: At, Mol, Opt Phys. 1988; 38:3098.

58. Perdew JP. Phys Rev B: Condens Matter Mater Phys. 1986; 33:8822.

59. Pantazis DA, Chen XY, Landis CR, Neese F. J Chem Theory Comput. 2008; 4:908-919. [PubMed: 26621232]

60. Neese F. Inorg Chim Acta. 2002; 337:181.

61. Klamt A, Schüürmann G. J Chem Soc, Perkin Trans 2. 1993; 2:799-805.

62. Grimme S, Antony J, Ehrlich S, Krieg H. J Chem Phys. 2010; 132:154104. [PubMed: 20423165]

63. Sinnecker S, Slep LD, Bill E, Neese F. Inorg Chem. 2005; 44:2245-2254. [PubMed: 15792459]

J Am Chem Soc. Author manuscript; available in PMC 2017 October 05. 


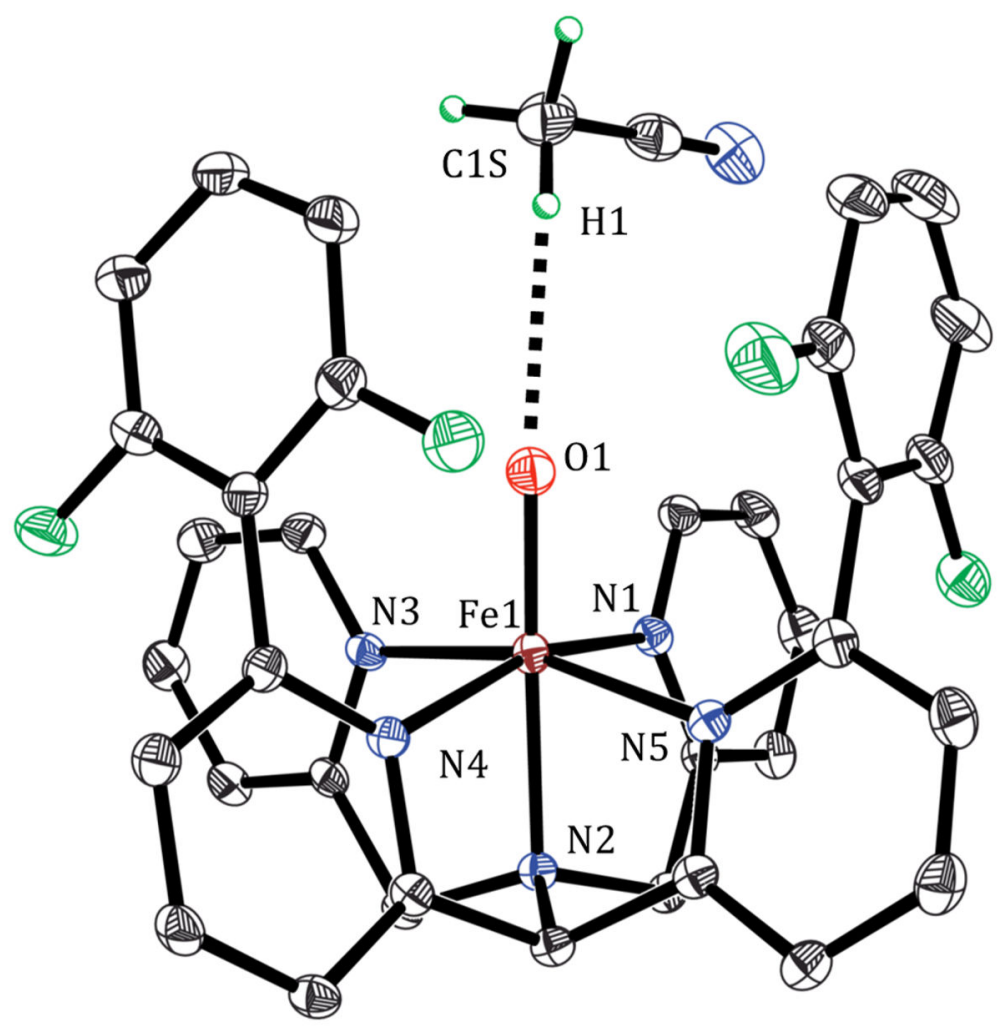

Figure 1.

Displacement ellipsoid plot (30\% probability) of the cation of 1-O at $110(2) \mathrm{K}$, depicting the $\mathrm{C}-\mathrm{H}$... O interaction in the asymmetric unit. All $\mathrm{H}$ atoms except for those in the $\mathrm{CH}_{3} \mathrm{CN}$ molecule were omitted for clarity. Selected bond distances: Fe1-N1 1.9730(18), Fe1-N2 2.0511(17), Fe1-N3 1.9771(18), Fe1-N4 2.0408(17), Fe1-N5 2.0269(17), Fe1-O1 1.6600(16). 


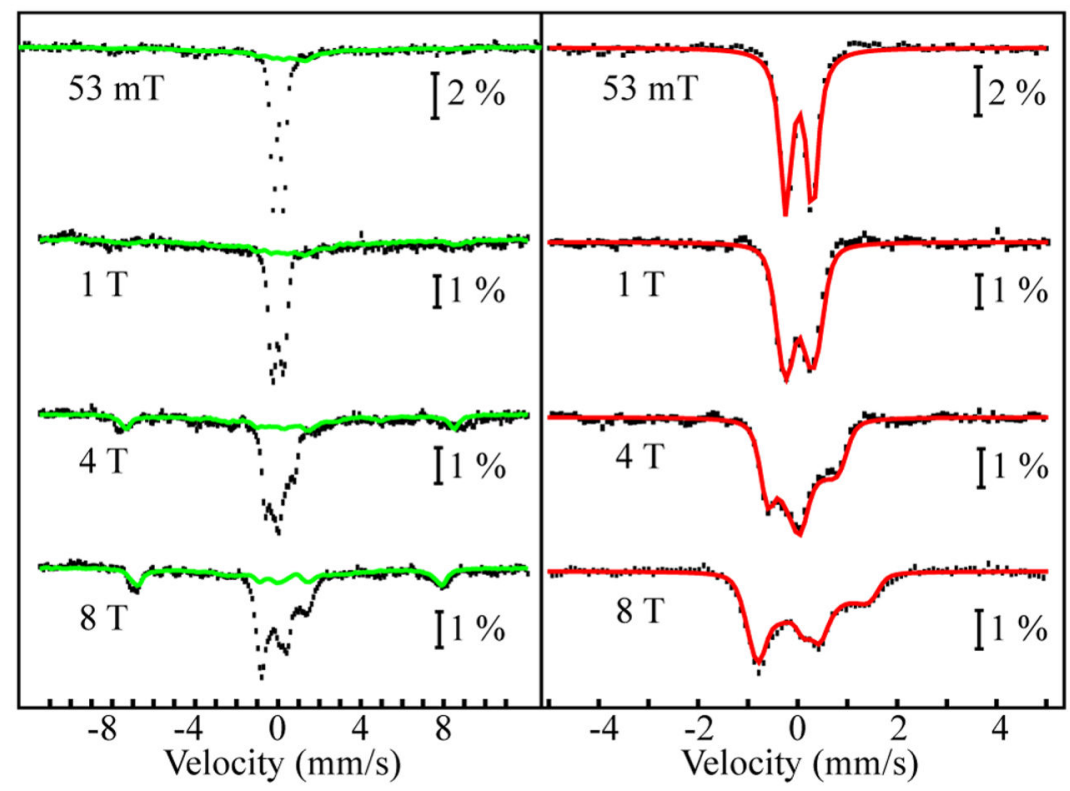

Figure 2.

4.2 K Mössbauer spectra of 1-O. Left panel: Spectra recorded in externally applied magnetic field with field strength indicated in the figure (black vertical lines). The solid green lines are the experimental spectra of a duplicate sample of $\mathbf{1}+\mathrm{IBX}$-ester reacted at $23{ }^{\circ} \mathrm{C}$ for $40 \mathrm{~min}$, scaled to $38 \%$ of intensity. Right panel: Reference spectra of 1-O generated by removal of the contribution of the decay products (black vertical lines). The solid red lines are simulations for $S=1$ spin Hamiltonian using the following parameters: $D=23 \mathrm{~cm}^{-1}, E / D=$ $0.08, g_{\text {iso }}=2.0, \delta=0.03 \mathrm{~mm} / \mathrm{s}, \Delta E_{\mathrm{Q}}=+0.54 \mathrm{~mm} / \mathrm{s}, \eta=0$, and $\mathbf{A}=(-29.1,-27.8,-6.5)$

$\mathrm{MHz}$. 


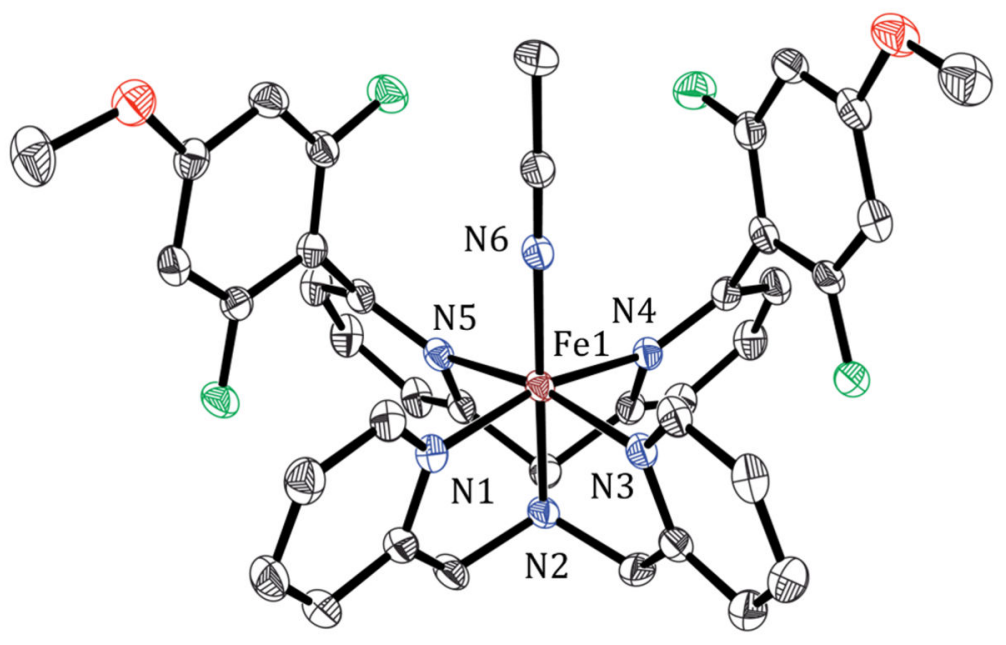

Figure 3.

Displacement ellipsoid plot (50\% probability) of the cation of 2 at $110(2) \mathrm{K}$. The $\mathrm{H}$ atoms were omitted for clarity. Selected bond distances (in A): Fe1-N1 1.9614(19), Fe1-N2 1.9599(19), Fe1-N3 1.949(2), Fe1-N4 2.0626(19), Fe1-N5 2.030(2), Fe1-N6 1.927(2). 

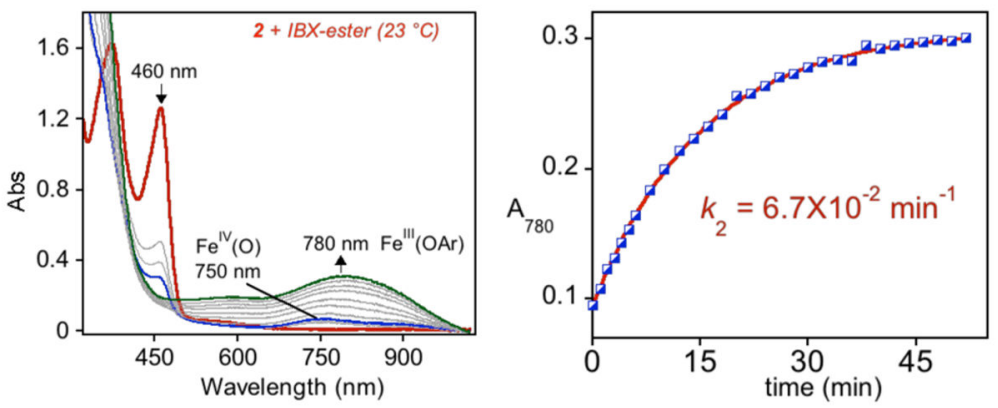

Figure 4.

UV-vis spectral changes for the reaction of $2(0.47 \mathrm{mM} ; 3.0 \mathrm{~mL})+$ IBX-ester (1 equiv) in $\mathrm{CH}_{3} \mathrm{CN}$ at $23{ }^{\circ} \mathrm{C}$ (left) and plot of $A_{780}$ versus time and best fit (red line, right). 


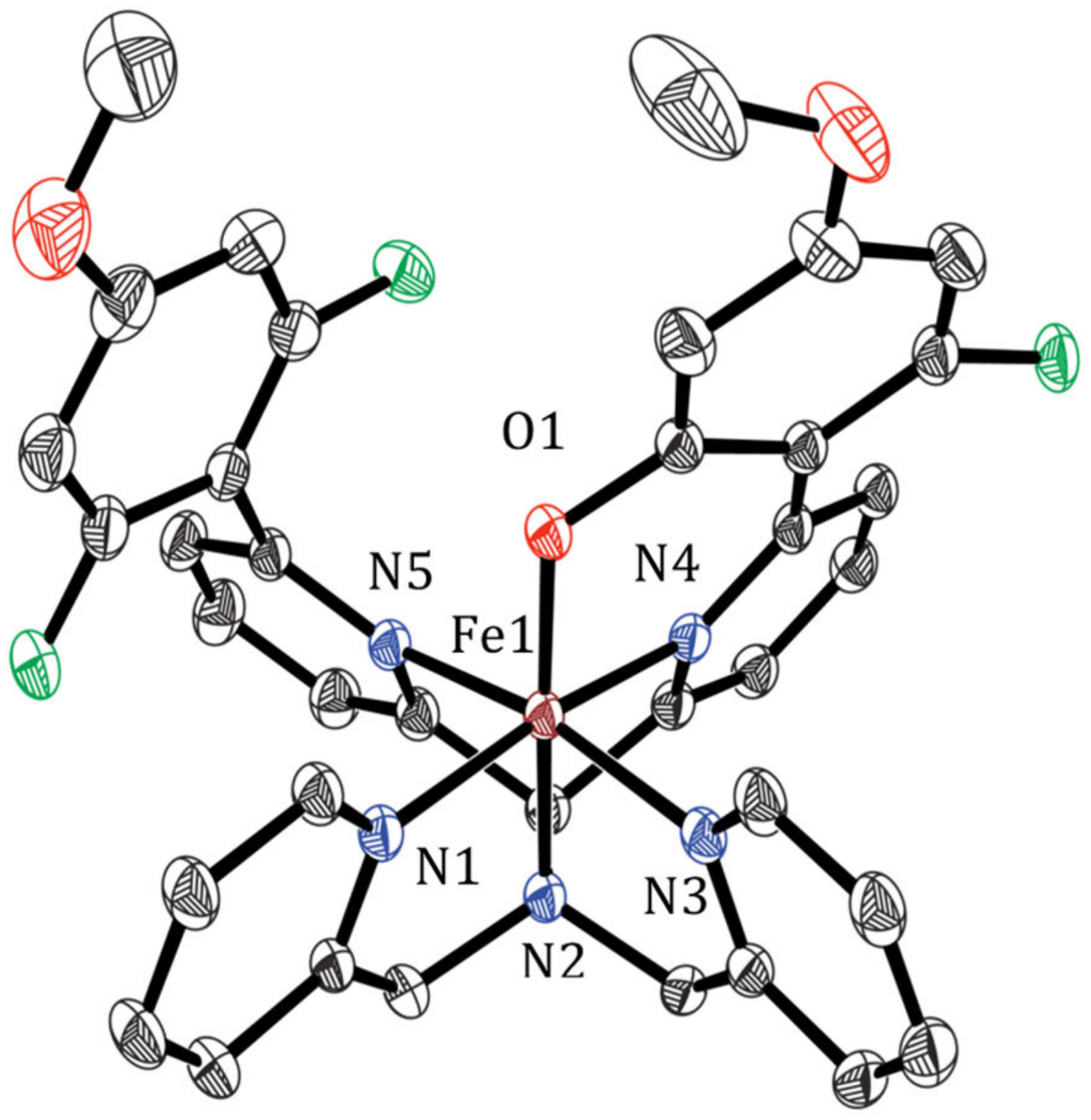

Figure 5.

Displacement ellipsoid plot (30\% probability) of the cation of 2-OAr at 110(2) K. H atoms were omitted for clarity. Selected bond distances (in Å): Fe1-N1 1.963(2), Fe1-N2 1.969(3), Fe1-N3 1.966(3), Fe1-N4 1.921(2), Fe1-N5 2.018(2), Fe1-O1 1.814(2). 


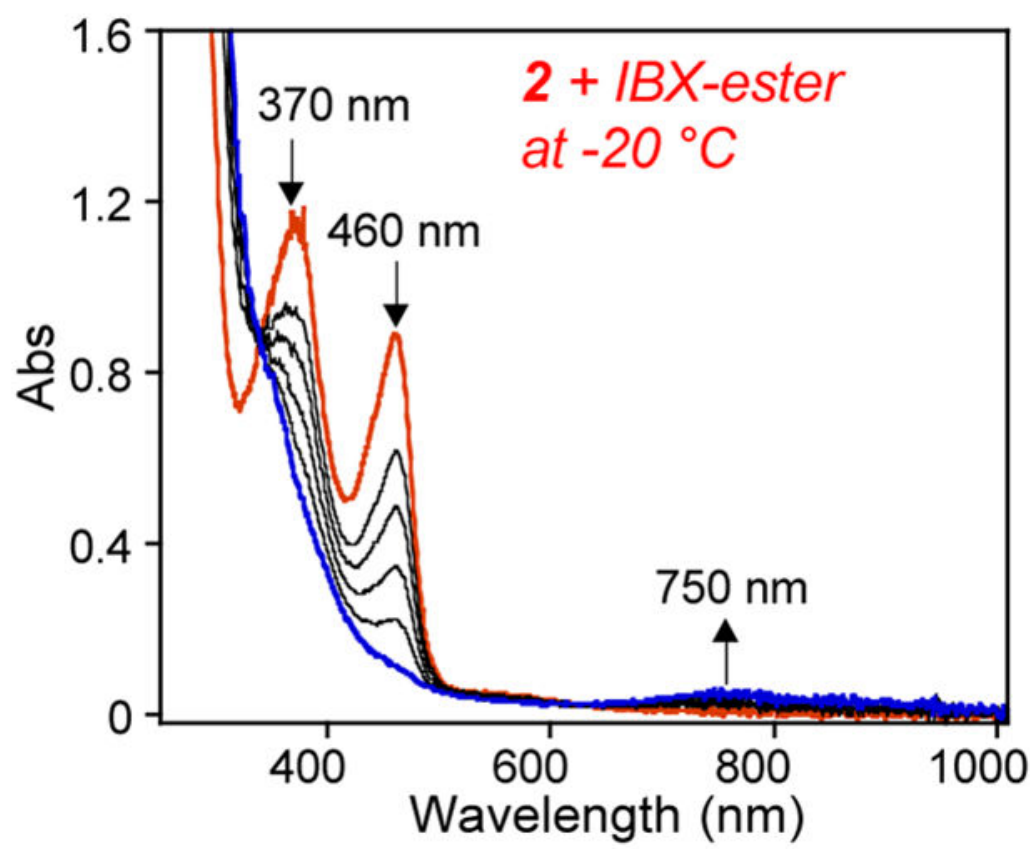

Figure 6.

Reaction of 2 (1.04 mM) with IBX-ester (1.5 equiv) at $-20^{\circ} \mathrm{C}$, monitored by UV-vis spectroscopy. 

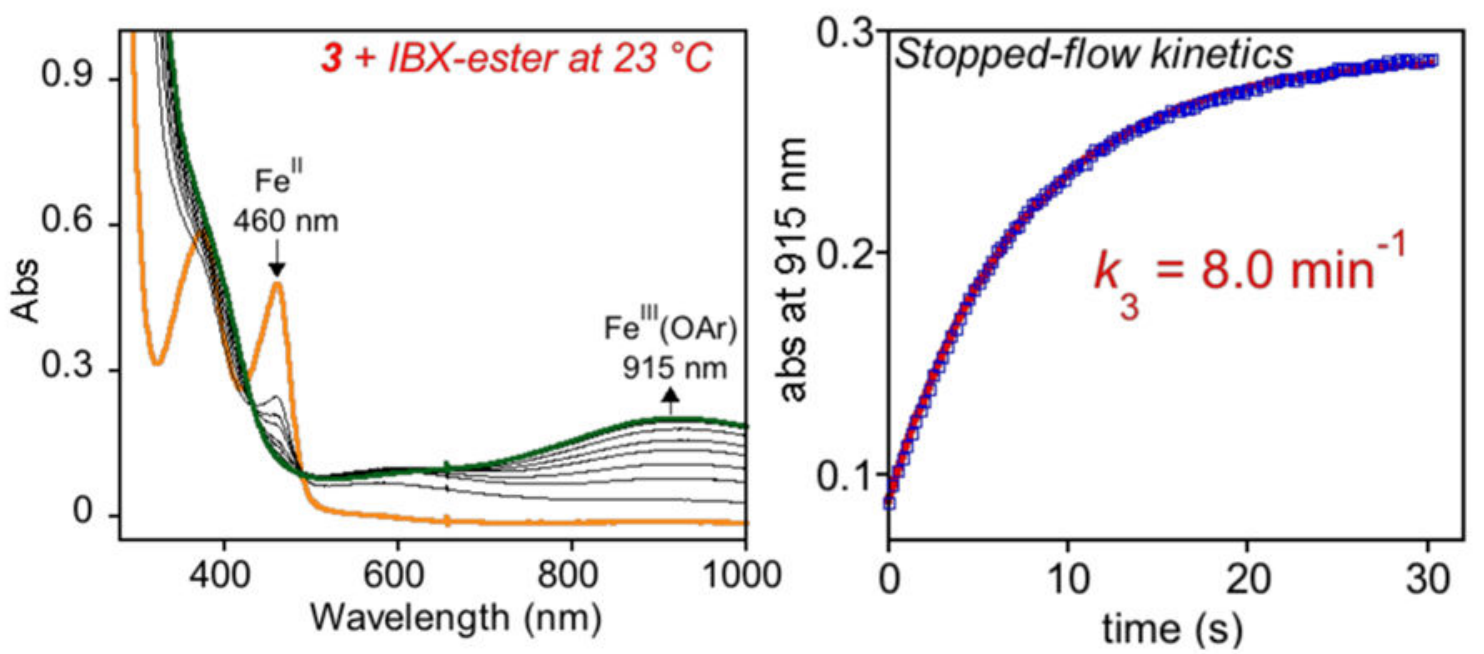

Figure 7.

$\mathrm{UV}$-vis spectral changes for $3(0.2 \mathrm{mM})+\mathrm{IBX}$-ester (1.1 equiv) in $\mathrm{CH}_{3} \mathrm{CN}$ at $23{ }^{\circ} \mathrm{C}$ (left). Plot of absorbance at $915 \mathrm{~nm}$ versus time obtained from stopped-flow UV-vis spectroscopy and the best fit (red line, right). 


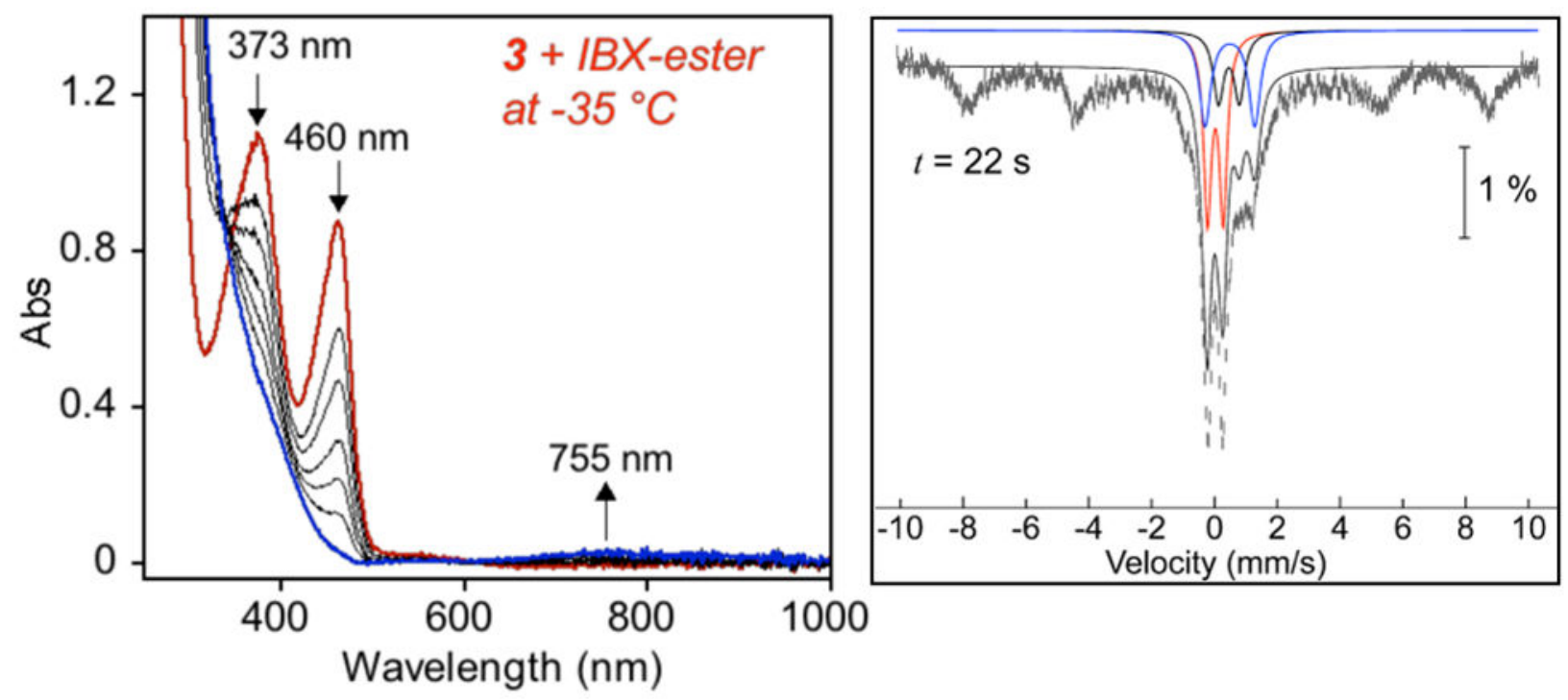

Figure 8.

UV-vis spectral changes for the reaction of $3(0.99 \mathrm{mM})$ with IBX-ester at $-35^{\circ} \mathrm{C}$ in $\mathrm{CH}_{3} \mathrm{CN}$ (left). Freeze-quench Mössbauer spectrum for $3(5 \mathrm{mM})+\mathrm{IBX}$-ester at $-5^{\circ} \mathrm{C}$ in $\mathrm{CH}_{3} \mathrm{CN} / 2-$ methylbutane after $22 \mathrm{~s}$ (right). The species are ls-Fe ${ }^{\mathrm{II}} \mathbf{3}$, thick solid black; hs-Fe ${ }^{\mathrm{II}}$ 3, dashed black; Fe ${ }^{\mathrm{II}}$ intermediate, blue; $\mathrm{Fe}^{\mathrm{IV}} \mathrm{O}$ intermediate, red; sum of fitted species, thin black line; Fe(III) products, unfitted. 


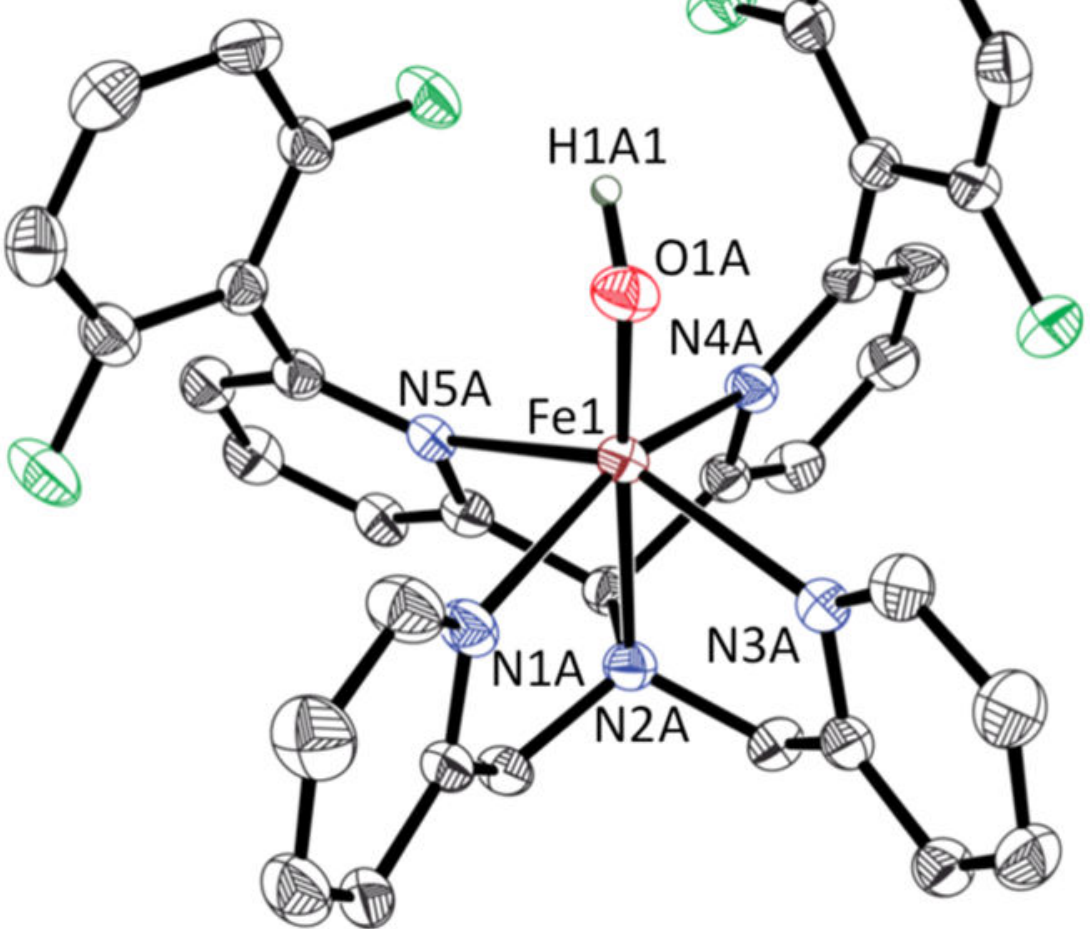

Figure 9.

Displacement ellipsoid plot (50\% probability) of one of the two crystallographically independent cations of $\mathbf{4}$ at 110(2) K. All $\mathrm{H}$ atoms were omitted for clarity (except for H1A1). Selected bond distances (in $\AA$ ) for one of the crystallographically independent units: Fe1-N1A 2.175(4), Fe1-N2A 2.269(4), Fe1-N3A 2.223(4), Fe1- N4A 2.251(4), Fe1-N5A 2.300(4), Fe1-O1A 1.914(3). 

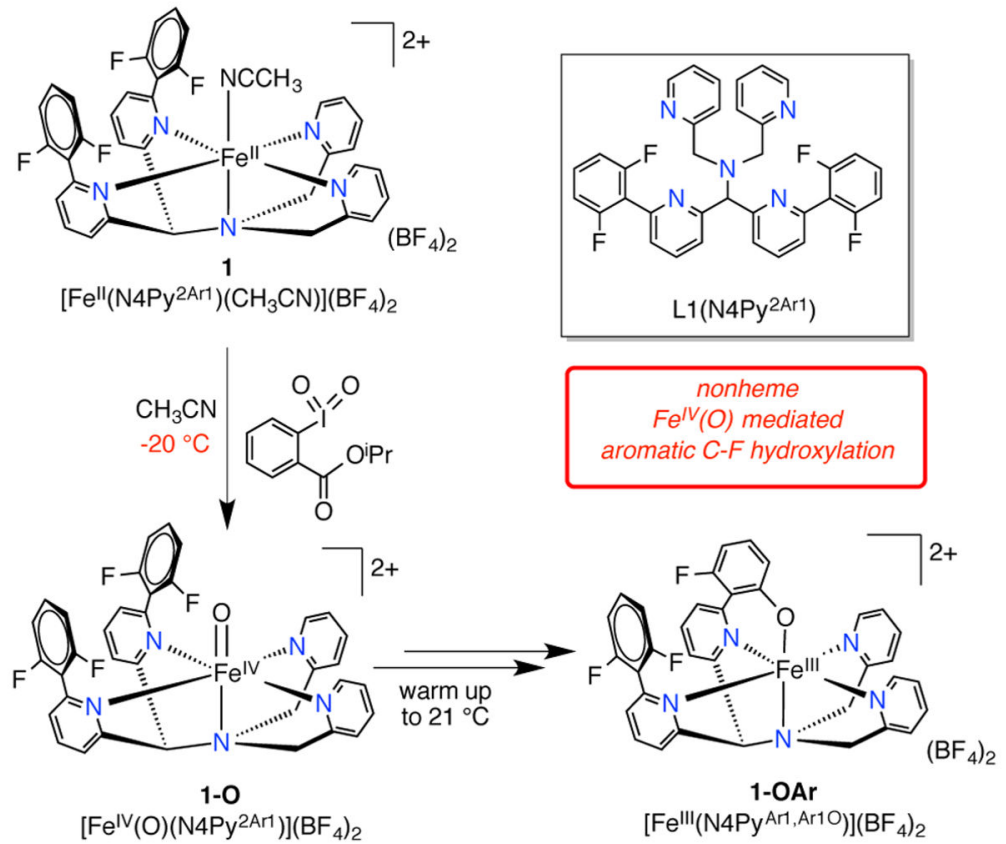

Scheme 1.

Ligand N4Py ${ }^{2 \mathrm{Ar}} 1(\mathrm{~L} 1)$ and the $\left[(\mathrm{L} 1) \mathrm{Fe}^{\mathrm{IV}}(\mathrm{O})\right]^{2+}$ - Mediated Aromatic C-F Hydroxylation 


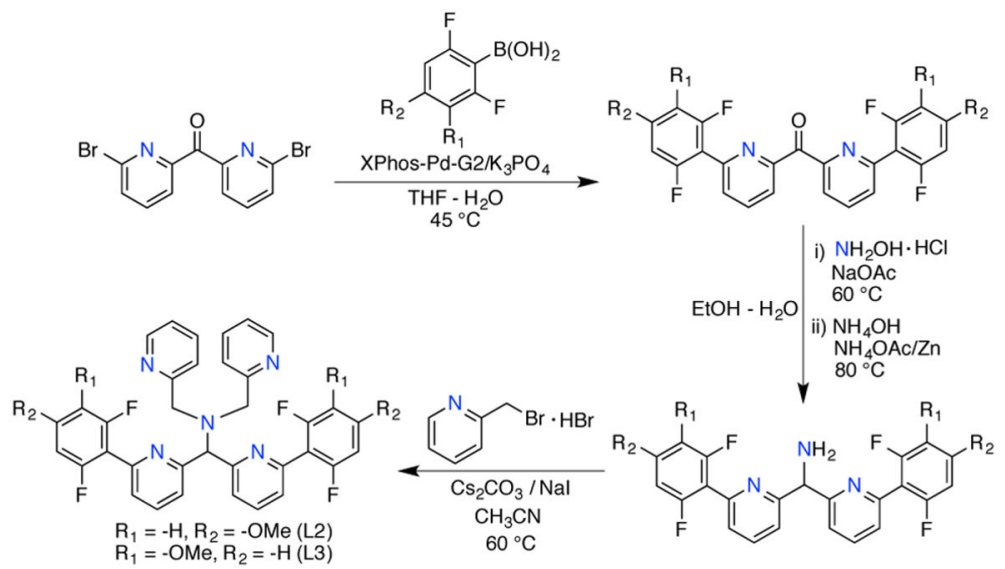

Scheme 2.

Synthetic Route for the Preparation of L2 and L3 


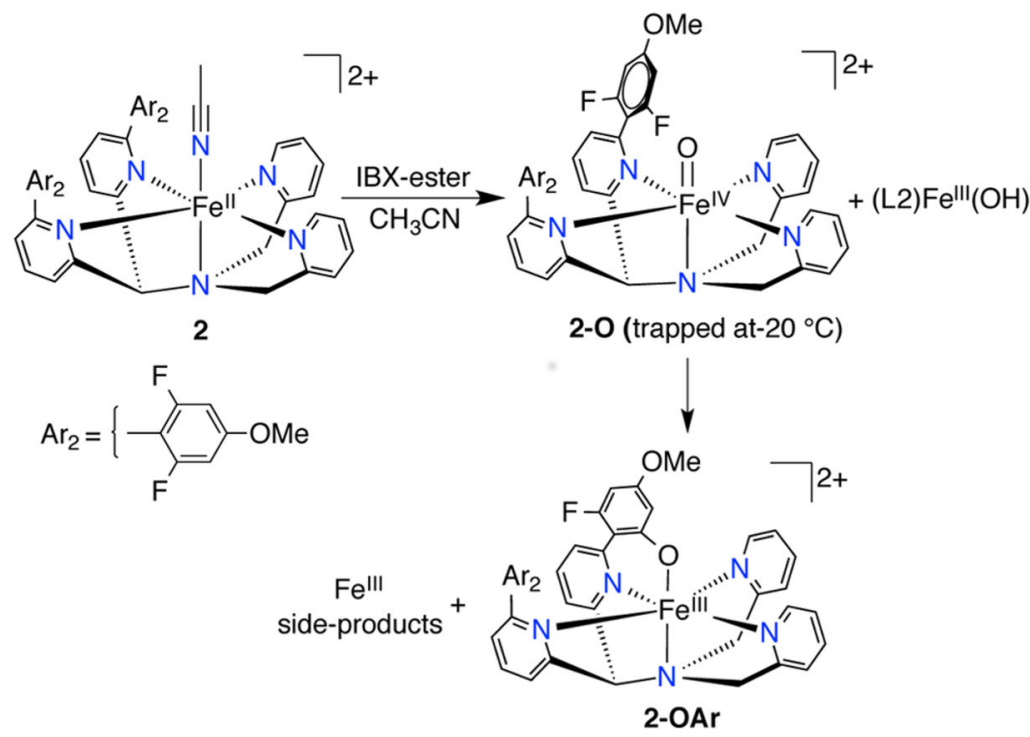

Scheme 3.

Conversion of 2 to 2-OAr 

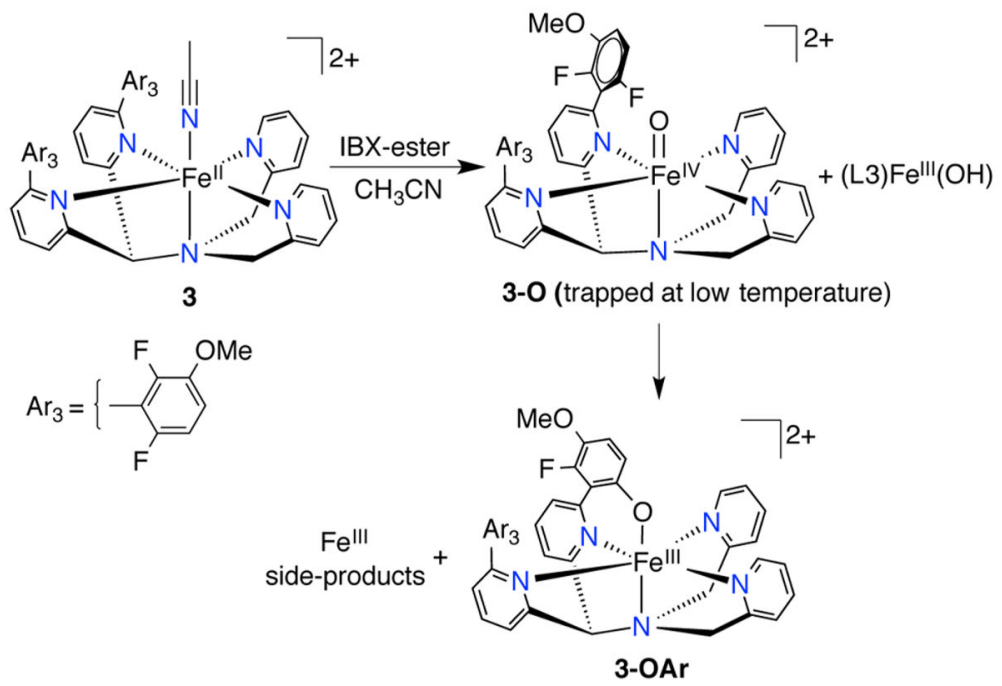

Scheme 4.

Conversion of 3 to $3-\mathrm{OAr}$ 


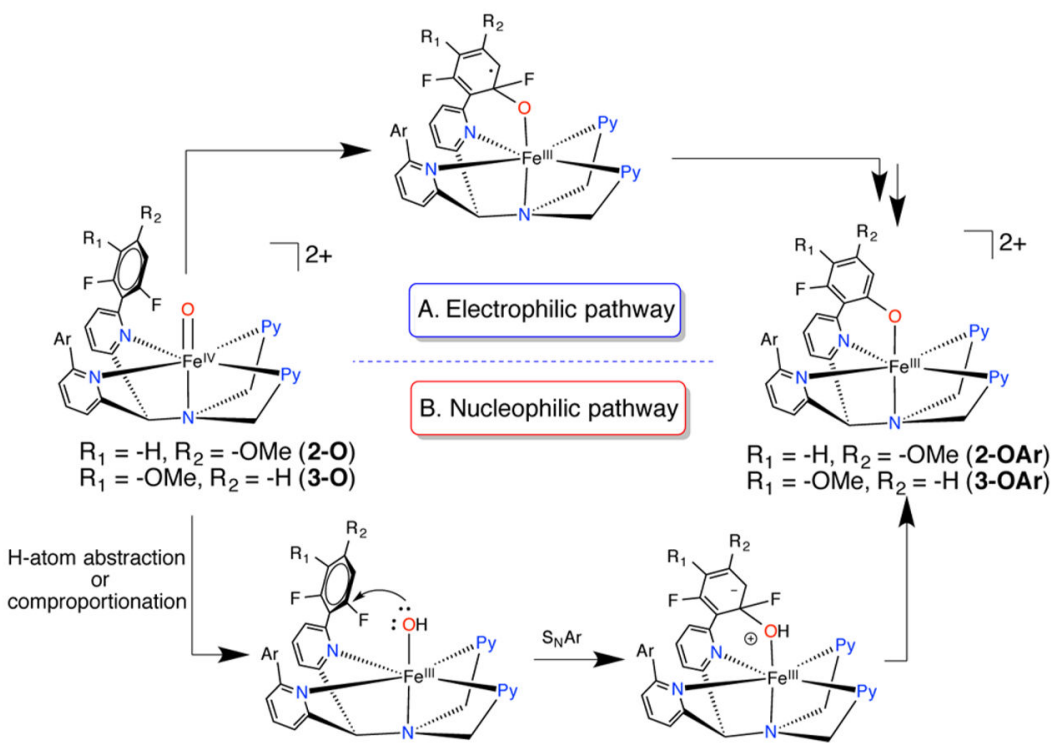

Scheme 5.

Possible Mechanistic Pathways for $\mathrm{Fe}^{\mathrm{IV}}(\mathrm{O})$ - Mediated Aromatic C-F Hydroxylation 


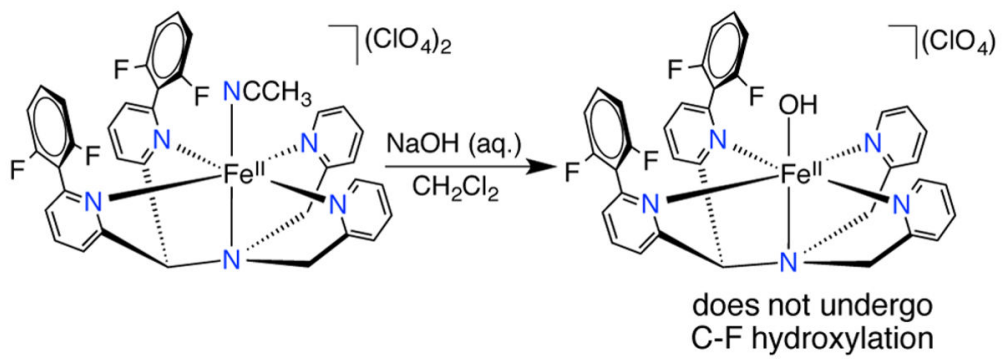

Scheme 6 .

Synthesis of $\left[\mathrm{Fe}^{\mathrm{II}}(\mathrm{OH})\left(\mathrm{N} 4 \mathrm{Py}^{2 \mathrm{Ar}_{1}}\right)\right]\left(\mathrm{ClO}_{4}\right)(4)$ 


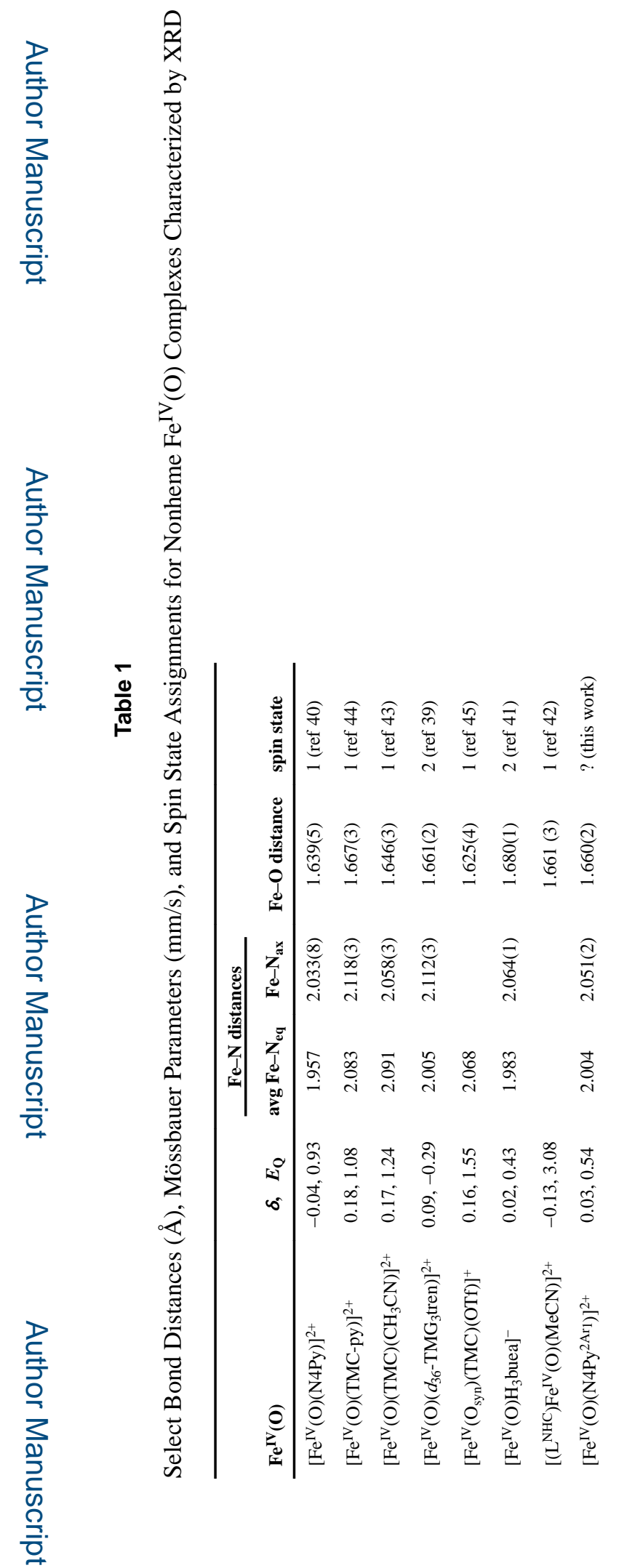

J Am Chem Soc. Author manuscript; available in PMC 2017 October 05. 


\section{Table 2}

Activation Parameters for the $\mathrm{Fe}^{\mathrm{IV}}(\mathrm{O})$-Mediated Arene Hydroxylation Reactions for 1-O to 1-OAr and 2 to 2$\mathrm{OAr}$

\begin{tabular}{ccccc}
\hline & \multicolumn{2}{c}{ 1-O to 1-Oar } & & \\
\cline { 2 - 3 } Parameters & exptl. & DFT $^{a}$ & 2-O to 2-Oar & 3-O to 3-OAr \\
\hline$\Delta H^{\ddagger} b$ & $17.4(0.4)$ & 16.9 & $20.5(1.4)$ & $12.0(0.9)$ \\
$\Delta S^{\dagger} c$ & $-12.7(1.4)$ & $-4.9^{d}$ & $-3.1(4.6)$ & $-14.1(3.2)$ \\
$\Delta G^{\natural} b, e$ & $21.2(0.6)$ & 19.65 & $21.4(2.0)$ & $16.2(1.3)$
\end{tabular}

The values in the parentheses are the respective errors.

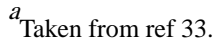

$b_{\text {In kcal mol}}-1$

$c_{\text {In cal mol }}^{-1} \mathrm{~K}^{-1}$

${ }^{d}$ Obtained from $\Delta G^{\ddagger}=\Delta H^{\ddagger}-T \Delta S^{\ddagger}$ at $298 \mathrm{~K}$.

$e^{e}$ At $298 \mathrm{~K}$. 